\title{
Alternative Dispute Resolution for Consumer Cases: Are Divergences an Obstacle to Effective Access to Justice?
}

\author{
Urša Jeretina \\ Professional trainee at Croatian Mediation Association (CMA) and Head of R\&D \\ Zavod UP - Institute for administration operations \\ ursa@zavod-up.si
}

\author{
Alan Uzelac \\ Professor of Civil procedural Law at the Zagreb University \\ Faculty of Law \\ auzelac@pravo.hr
}

\section{ABSTRACT}

Traditional court proceedings do not always offer practical and cost-appropriate way of resolving consumer disputes. Some authors consider that, in disputes between consumers and businesses, alternative dispute resolution (ADR) is more effective, faster and cheaper. Insofar, consumer ADR (CADR) is seen as a useful instrument that helps consumers realize their right of access to justice. It is argued that the CADR is a flexible and faster method of enforcement of consumers' rights, and that CADR systems provide valuable information on the needs of applicants, while preserving confidentiality and increasing consumer satisfaction. However, while praised in theory, the CADR in real life has not reached the desired levels. It seems that both sides, businesses and consumers, lack awareness of ADR schemes and their benefits. In this paper we analyze the concept of CADR through compensatory collective redress. Special attention is paid to different barriers for the development of various ADR schemes, which are also reflected in the evaluation methods used to measure efficiency of the use of the (C)ADR. The EU Directive on Consumer ADR and Regulation on Online Dispute Resolution (ODR) have attempted to set flexible rules that would assure quality of dispute resolution between entities in the EU. However, the EU initiatives so far leave many questions unanswered, in particular about supervision and financing of CADR schemes, as well as the issues regarding purely internal harmonization of CADR practices. An example for considerable divergences are CADR proceedings in the neighboring Western Balkan states, such as Slovenia and Croatia.

Key words: consumer alternative dispute resolution, consumer protection, ADR schemes, collective redress, harmonization of EU law, CADR schemes in Slovenia and Croatia 


\section{Introduction}

Effective consumer protection is one of the key elements for the functioning of the EU internal market. Functioning of the EU single market is beneficial for consumers and businesses; it supports creating jobs and promoting growth, competitiveness and innovation. However, EU could offer a more unified internal market in key sectors of everyday life, such as energy and telecommunications, as well as in sectors that are fragmented or obviously lack effective competition.

The consumer is a weaker party in every process of dispute resolution. Consumers do not know enough about the quality and characteristics of technically advanced and/or demanding products, and lack comprehensive knowledge about the quality standards pertaining to services. They are unable to assess the risk of particular contracts, while they are heavily exposed to psychological pressure of advertising (Zabel, 1999, p. 468). In addition, judicial proceedings can be long and complex. The losses suffered by European consumers due to the problems with purchased goods or services are estimated at 0,3\% of the European GDP ${ }^{1}$. This estimate particularly targets small claims in which consumers, harmed by an illegal practice of a trader, face difficulties in accessing effective and affordable means to obtain appropriate compensation. Essentially, for the amounts below 200 EUR, $48 \%$ of the EU consumers do not initiate court proceedings, while $8 \%$ of them never do so irrespective of the amount of their claim² (Directorate General for Health and Consumers - DG SANCO, 2011, pp. 3-5).

Consumer Alternative Dispute Resolution (CADR) can help enterprises to maintain good relationships with consumers and gain a positive reputation in the EU internal market. It also promotes competition. But, the main advantage of the efficient use of CADR and Online Dispute Resolution (ODR) in consumer matters is the increased satisfaction of the users that get another option to protect their rights - a process that is fair and appropriate, and uses of simpler, cheaper and faster dispute resolution methods.

The ADR methods may be used in relation between consumers and businesses (C2B or B2C) or in relations between businesses (B2B). In any case, the process presupposes the involvement of an independent and neutral third party - a mediator, conciliator, ombudsman or similar person. The CADR procedure seeks to secure interaction between the parties and facilitates finding of consensual solutions. For instance, consumers are actively involved in the dispute settlement procedure - be it mediation, conciliation or negotiation - and participate in the process of finding effective redress for their violated rights.

1 See for example The Gallup Organization (2011), Flash Euro barometer No. 299, "Consumer attitudes towards cross-border sales and consumer protection".

2 See for example TNS Opinion \& Social (2011), Special Euro barometer No. 342, "Consumer Empowerment". 
In practice, there are more than 750 different ADR schemes (DG SANCO, 2011, p. 6). They are all based on different procedures carried out by different entities. The EU proclaimed that consumer ADR can be carried out both as a civil or as an administrative procedure. The choice of procedure is left to the Member States. The result of this freedom of choice is divergences in various areas. In some of them, e. $\mathrm{g}$. in the areas of energy, telecommunications, e-communications, postal services and transport, if no settlement can be reached, the dispute resolution continues in an administrative procedure, even if the dispute apparently deals with private interests only. The relationship between the consumers or users of these services and their operators is by the EU "acquis" defined as the use of "services of general interest" or "universal service obligation - USO". Such services are considered to be carried out as administrative matters that fall under the public administrative law. In such "administrative" ADR proceedings the public interest in the protection of market is matched by the interest in protection of the weaker party - the consumer. If public interest prevails, the administrative proceedings may be supervised by different administrative entities (e. g. regulatory agencies or the ombudsman). In some Member States such agencies, because of their independence and autonomy, conduct ADR proceedings and may issue final administrative decisions. Such decisions are binding for the trader, but the consumer has the right to appeal the decision before the Administrative Court. Resolving these disputes may therefore take form of a multi-stage proceedings, initially conducted under the Administrative Procedure Act (APA), and then before regular courts. It is considered that the said administrative dispute resolution is not a form of ADR (Galič, 2012, p. 6), although administrative ADR (especially negotiation rulemaking) has been introduced in United States in APA (article 571-584) in the mid-1970s' (Henry \& Perritt, 1987, p. 863), and is also increasing in several EU Member states e. g. the practice in Sweden, Belgium, Finland, Norway etc. (Lindell, 2012, p. 312) with the move towards a more bilateral relationship between administration and citizens (as consumers), but because of the specific character of public law some problems have occurred (Goes, 2014, p. 9). After Perritt (Henry \& Perritt, 1987, p. 863) in administrative law "a major discrepancy between administrative procedure and the decision-making requirements of delegated legislative power was a failure to distinguish 'rights disputes' from 'interest disputes'." The problem is that "interest disputes" are characterized by the absence of pre-existing rules of decision, because adjudication is dealing just with "rights disputes" written by the law. Essentially, there is a need to develop a coherent ADR framework not just for civil proceedings, but also within public administrative law across all Member States.

The purpose of this paper is based on normative and comparative analysis to determine the key positive (benefits) and negative (divergences) aspects of the ADR concept in consumer matters, with exploration whether the current legal status of the $\mathrm{EU}$ is contributing to increasing of consumer confidence in the single market across all EU Member states. The objectives are realized 
through different empirical analysis of the use of (C)ADR through compensatory consumer redress, which have shown the existence of various ADR schemes through different legal frameworks across EU and also divergences in CADR proceedings with different legal relationships for example in Western Balkan states (Slovenia and Croatia). The main aim of the survey is to present the complete and realistic picture of the use of (C)ADR and future guidelines of the need for EU action, which would serve to create a more coherent and partnership legislation for the development of harmonized (C)ADR model in administrative and judicial proceedings in the terms of "good governance", and ultimately to reply to the question raised in the title of this article.

\section{The Benefits of CADR}

The cross-border economic cooperation stimulates growth of the number of providers on the market. This creates a favorable competitive climate among providers and has a beneficial impact on prices of goods and services. The movement of goods and people is on the rise. While the EU policies aim to reach high level of consumer protection, in practice it is still difficult for consumers to enforce their rights when such a need arises. In addition, Europe needs new sources of growth and consumer policies should assist that goal.

The Europe consists of 500 million consumers and consumer expenditures amount to $56 \%$ of the EU GDP (European Commission, 2011a, p. 2). The European consumers' skills and capability are nowadays representing an "intangible stock of capital", which means that empowered consumers will boost competition and innovation, they will strongly influence economic growth and sustainability with also forcing businesses to deliver value on the market (Davies, 2012, p. 63). Innovation delivers value to the market, which means authentic commitment to trying something new and retaining an open mind to the results in practice (Macfarlane, 2012, p. 939). The effective innovation in practice is empowering consumers with full confidence and changing the tradition of resolving their disputes (small claims), which are so far too expansive.

The Europe 2020 Strategy calls for "citizens to be empowered to play a full role in the single market', which 'requires strengthening their ability and confidence to buy goods and services cross-border". In today's modern world with globalized and digital economy, consumer empowerment and confidence plays a key role in the single market (DG SANCO, 2011, p. 3). The consumers'

3 See European Commission (2010), Europe 2020, a strategy for smart, sustainable and inclusive growth, which proposes seven important initiatives: 1. an innovation Union, 2. youth on the move, 3. a digital agenda for Europe, 4. a resource-efficient Europe, 5. an industrial policy for the globalized era, 6. an agenda for new skills and jobs and 7. a European platform to tackle poverty (p. 5). 
trust in the Single Market is adversely affected by the lack of confidence ${ }^{4}$, which can be restored only by encouraging active participation of consumers in the functioning of markets and achieved by empowerment of their rights (European Commission, 2011, p. 2). EU Consumer Policy Strategy (20072013) ${ }^{5}$ defines 'empowered consumers' as consumers with real choices, full accurate information, market transparency and the confidence that comes from effective protection of their rights. The Strategy emphasizes the importance of empowerment, which comes from the capacity of well-informed consumers and also from designed efficient infrastructural framework that can highlight consumer's actual behavior in the market.

Building an overall environment with "smart" policies where consumers can rely on the basic premise of safety through education is not an easy task. What needs to be provided is information on sometimes complex ways of navigating through the Single Market. It is the only way to empower the consumers and help them to effectively benefit from the best offers on products and services. Only in such an enviroment the consumers will be able to confidently exercise their rights knowing that they have access to efficient redress in case of violations. If more consumers are able to make informed decisions, they could also have the greater impact on strengthening the Single Market and stimulating growth by demanding value, quality and service (European Commission, 2011a, p. 2). Access to effective enforcement and efficient redress means to resolve disputes and obtain compensation for consumers when their rights are violated by traders. The indispensable tools for effective protection of consumers' rights are ADR and ODR schemes, which can put empowered consumers at the heart of the Single Market (European Commission, 2011, p. 2).

\subsection{The advantages of Consumer Alternative Dispute Resolution (CADR)}

ADR and ODR techniques are increasingly used together or combined for inclusion in the formal legal system at the international level. The essence of ADR/ODR procedures is voluntary access of parties in the process and neutrality of the third party (e. g. mediator etc.), which is conducting this confidential proceeding, where jurisdiction is in the hands of the parties themselves. The key advantages of consumer ADR and ODR proceedings are therefore mainly in the scope and role of the parties involved, in lower costs and in fastest final decision of the proceedings, which we listed below.

4 More than $26 \%$ Europeans do not feel confident as a consumer, 36\% Europeans do not feel knowledgeable as a consumer and $40 \%$ Europeans do not feel protected by consumer law. See TNS Opinion \& Social (2011), Special Euro barometer No. 342, Consumer Empowerment, p. 5.

5 See the Communication from the Commision to the Council, the European Parliament and the European Economic and Social Committee (2007), EU Consumer Policy Strategy 20072013, Empowering consumers, enhancing their welfare, effectively protecting them. Brussels, COM (99 final). 
Table 1: Main advantages of ADR and ODR proceedings in consumer matters

\begin{tabular}{cc}
\hline Advantages of ADR & Advantages of ODR \\
\hline -suitability for multi-party disputes & - easy online platform ADR = ODR presen- \\
-flexibility of the procedure - the proce- & ted with instructions for use in several \\
dure is defined and controlled by the & languages for cross-border disputes \\
parties to the dispute & between the parties primarily consumer- \\
-lower costs & -trader \\
-reduced complexity in the sense of »less & - providing electronic complaint form \\
is more» & - defining the competent authority ADR, \\
-parties choice of neutral third party & which the parties agreed to, and forwar- \\
(expertise in the field of conflict) for & ding the complaint \\
direct negotiations or termination & - free electronic tools (e-mail, mobile \\
of the proceeding & messages etc.) to ensure communication \\
-the likelihood and speed of decision & between the parties and the ADR bodies \\
within a maximum of 3 months & to forwarding the request \\
-practical solutions tailored to the inte- & -the digital platform for the translation \\
rests and needs of the parties involved & of information between the parties and \\
(and not the rights and wishes, it can be & the ADR body (accessible in different \\
perceived) & languages) \\
-sustainability agreements & - electronic archive files: the proposal for \\
-confidentiality, neutrality and voluntari- & ADR, selection of ADR body, record of \\
ness & dispute, agreement on ADR procedures, \\
-maintaining interpersonal relationships & the settlement of resolving the dispute \\
and reputation rating & (or loss) \\
-the possibility of collective redress (the & - tendency to resolve the dispute within \\
general interest of consumers) & 30 days from the date of receipted \\
& request in consideration \\
& - automatic feedback on receiving reque- \\
& sts / information etc. \\
& - confidentiality, informality, the voluntary \\
& nature of the process \\
& - the protection of personal data \\
& - easy online platform ADR = ODR \\
presented with instructions for use \\
in several languages for cross-border \\
disputes between the parties primarily \\
consumer-trader \\
\hline
\end{tabular}

Source: Adopted after Directive on Consumer ADR, 201b; Hodges et al., 2012d, pp. 22-23; Regulation on ODR, 2013a; Rous, 2014, pp.16-17 and authors own.

Above advantages show the need of implementation of ADR schemes to public bodies and the implementation of latest techniques of ODR, which is the result of multi complexity and the rapid development of the Network. In some Member States (Belgium, Netherlands, UK and others) ODR is already fully implemented in their legal systems as on-line process of resolving virtual consumer disputes.

In the future The EU Regulation on Online Dispute Resolution (2013) and European program 2020 have and will provide a new option for all Member States for resolving cross-border disputes between traders and consumers via digital platforms. Advantages of the virtual settlement for consumer disputes are not only voluntariness, informality and privacy of procedure, but also the faster final decision of cross-border dispute within thirty days. Important role and increased responsibility will be given to "virtual mediators", which will vir- 
tually facilitate parties from different Member States to the consensual decision on digital platform. ODR platform is easy to use with instructions in all European languages (online "Portal Your Europe"), which is pay-free available to all citizens and businesses in the EU.

ODR procedure is extremely confidential, where information exchange enjoys strict protection of the data, although their use is transparent. Member States which have not yet adopted ODR implementation - will be set up in four phases, the main elements of proposal of which are (Hodges, 2012, pp. 30-31, Hodges et al. 2012d, pp. 22-23, Rous, 2014, pp. 16-17):

1. Establishment of the European ODR system: The European Commission will with implementing acts adopt measures to establish an online platform, which should be surrendered in the first test of the technical functionality and suitability of usability by the end of 2015;

2. Information on the EU-wide ODR system: The European Commission should ensure the establishment of a network of national contact points (e. g. interconnection of ADR entities of all EU Member States);

3. Data Protection Rules: ADR schemes will be stored in databases and will be subject to the relevant legislation on data protection, which will ensure widespread availability;

4. Monitoring: The compliance by ADR schemes with obligations set out in this Regulation will be monitored by the competent authorities to be established in the Member States. The final adoption of a comprehensive regulation to use ODR will be in the beginning of 2016, which will be also followed by cyclic reports to the European Parliament on the introduction of the overall performance of the ODR platform. Member States will then gradually implement ODR platform no later than till 2017, but first they should implement various forms of ADR by the end of 2015.

However, many of the advantages of ADR or ODR depend on personal competences and "proper" skills of the involved third naturally party - "mediator", the sensitivity of a policy maker to the recognition of the real needs of interest groups or involved parties, and the creativity of administrative lawyer in structuring a process that will serve the spirit of the Administrative Procedure Act and all other substantive rules/statutes (Henry \& Perritt, 1987, p. 928). Mediator has to be multidisciplinary person with psychology, social, law and other knowledge and skills as all in one, to help involved parties with different views and needs to find a compromise as the common interests.

\section{Current Legal Status of ADR in Consumer Matters}

The reasons why the European Commission developed an increased interest in the consumer ADR are mainly contained in its capacity to assure accessibility, equity, effectiveness, accountability and verification (Hodges et al., 2012, 
pp. 1-2). ADR is a political priority for the EU, which EU institutions are promoting together with ODR.

The legal basis for consumer ADR regulation in EU is provided by Article 114 and 169 of the Treaty on the Functioning of the European Union (hereinafter - the TFEU) $)^{6}$. TFEU gives particular importance to consumer protection in terms of supporting the interests of consumers, providing high consumer protection and promotion of their rights by awareness building, education and self-organization for the protection of their interests. The first steps in promoting consumer ADR schemes were highlighted as "soft law" in two European documents. The first one was Commission Recommendation on the principles applicable to the bodies responsible for out-of-court settlement of consumer disputes ${ }^{7}$. This document sets out seven principles, which must be taken into account by the authorities in each Member State and their bodies that provide services for resolution of consumer disputes. The second document was Commission Recommendation on the principles for out-of-court bodies involved in the consensual resolution of consumer disputes ${ }^{8}$, which provides additional four principles to ensure greater choice and flexibility for consumers, particularly with respect to electronic commerce and the development of communication technology.

In 2002, the European Commission drafted the Green Paper on Alternative Dispute Resolution in Civil and Commercial Law ${ }^{9}$ with the objective to initiate a broad-based consultations of those interested in legal issues which arise in regard to ADR in civil and commercial law. The Green paper has outlined three main reasons for growing interests in ADR:

1. Increasing awareness of the ADR as a means of improving general access to justice in everyday life,

2. Considerable attention that ADR has received in a number of Member States,

3. Attribution of a political priority to ADR in the context of the information society and the promotion of ODR. ${ }^{10}$

In terms of EU sector-specific legislation there are a number of EU directives, which contain provisions on ADR schemes for consumer disputes, such as

6 TFEU, OJ L EU, No. 83/2010, pp. 47-199. Article 114 regulates EU competences for the approximation of the laws concerning the establishment and functioning of the internal market, while article 169 lists the EU competences for promotion of the interests of consumers and ensuring a high level of consumer protection. See also Juškys and Ulbaitė, 2012, p. 26.

7 Commission Recommendation 98/257/EC of 20 March 1998, OJ L 115, 17. April 1998. It establishes the principles of independence, transparency, adversarial principle, effectiveness, legality, liberty and representation.

8 Commission Recommendation 2001/310/EC of April 2001 on the principles for out-of-court bodies in the consensual resolution of consumer disputes (2001/310/EC), OJ L 109, 19. April 2001. It sets out the principles of objectivity, transparency, efficiency and fairness.

9 The Green paper on Alternative Dispute Resolution in Civil and Commercial Law (2002), COM (196 final).

10 lbid., in summary. 
Directive on credit agreements for consumers ${ }^{11}$, Directive on electronic commerce ${ }^{12}$, Directive concerning common rules for the internal market in electricity ${ }^{13}$ etc. The incorporation of provisions of the new EU legal framework for consumer disputes of this kind indicates the increasing support of ADR in consumer matters. Yet, it is questionable whether the existing European legislation can assure a consistent development of quality ADR providers in the Member States.

Most consumer ADR schemes do not distinguish between the purchase of goods or services by distance sales (co-called "e-commerce") and the methods of direct sales (personal sales). They tend to resolve all kinds of disputes in the area of their jurisdiction, regardless of whether it is electronic or conventional purchase (DG SANCO, 2011, p. 10). In order to increase consumer confidence in the single market, the European Commission submitted two legislative recommendations with a view to subsequent regulation: proposal for a directive on alternative dispute resolution for consumer disputes in the single market ${ }^{14}$ and the proposal for a regulation on ODR ${ }^{15}$. The Directive on consumer ADR aims to encourage formation of high-quality bodies for resolving contractual disputes related to the sale of goods and provision of services by traders. Regulation on ODR should enable businesses and consumers to directly access an online platform, established at an intermediary body in accordance with Directive as assistance in resolving contractual disputes related to cross-border online transactions. The European Commission regulations are part of the twelve key actions of the Single Market $\mathrm{Act}^{16}$ that should contribute to formation of a "strong, deep and integrated" European market which "creates growth, generates jobs and offers opportunities"17.

The new EU consumer agenda (2014-2020) ${ }^{18}$ with DG-SANCOs Management Plan (2014) support the new policy aim that empowered consumers are the heart of the Single Market. This Agenda will achieve the aim with contributing to protection of health, safety and economic interests of consumers and promoting their right to information, education and to organize themselves

11 Directive 2008/48/EC on credit agreements for consumers and repealing Council Directive 87/102/EEC, OJ L 133/66, 66.

12 Directive 2000/31/EC on certain legal aspects of information society services, in particular electronic commerce, in the Internal Market (Directive on electronic commerce), OJ L 178/1.

13 Directive 2009/72/EC on concerning common rules for the internal market in electricity and repealing Directive 2003/54/EC, OJ L 211/55, Directive 2009/73/EC concerning common rules for the internal market in natural gas and repealing Directive 2003/55/EC, OJ L 211/94, pp. 55, 94.

14 Commission (EC) "Proposal for a Directive on alternative dispute resolution for consumer disputes and amending, Regulation 2006/2004/EC and Directive 2009/22/EC (Directive on consumer ADR)", COM/791 final, 29. November 2011.

15 Commission (EC) "Proposal for a Regulation on online dispute resolution for consumer disputes (Regulation on consumer ODR)." COM 794/2 final, 29. November 2011.

16 See European Commission (2012a). Single Market Act II, Together for new growth, COM (573 final).

17 Ibid., p. 4.

18 European Commission (2014), Consumer programme 2014-2020, see more on http://ec.europa.eu/consumers/strategy-programme/financial-programme/index_en.htm. 
to protect their interests also on Digital platform. The main problems that need to be addressed are signed in following categories with specific aims for consumer policy (DG-SANCO, 2014): Security (enhance product safety through effective market surveillance throughout the EU), working for and with consumers (increasing visibility of EECs), making markets work for consumers (to adopt proposed measures for greater transparency and comparability of bank fees, flexibility of transfers of payment accounts), going digital (implementation of Digital Agenda 2014 - "EU consumer in the digital era"), strengthening rights and redress (enforcement of consumer redress to consolidate consumer rights), enhancing knowledge ("know how" through the "Consumer Scoreboard") and ensuring better implementation and enforcement (to unlock the full potential of the Single Market with enforcement of consumer rights by strengthening cooperation between national enforcement bodies through Consumer Protection Cooperation (CPC) network).

\subsection{The Need for Action at the Level of the European Union}

The starting assumption of the European programmatic documents is that, if the development of ADR is left to the Member States' action alone, quality ADR schemes will continue to be absent in some sectors of the retail market and in some geographical areas of the EU (European Commission, 2011b, pp. 6-7). Recent studies show that the number of disputes submitted to ADR, including ODR, has increased in the EU from 410.000 in 2006 to 530.000 in 2008 (DG SANCO, 2009, p. 13). Although in 2009 only $3 \%$ of European consumers took their case to an ADR entity, only $9 \%$ of European retails have used ADR and only $6 \%$ of European traders are members of an ADR scheme (DG SANCO, 2011, p. 7). The diversity and uneven geographical and sectoral availability of ADR entities prevent consumers and businesses from fully exploiting their whole potential (European Commission, 2011b, p. 6). Relevant barriers also include non-compliance by businesses with non-binding decisions of ADR schemes and refusal by businesses to enter into out-of-court procedure, which can ultimately undermine consumer trust in such schemes, as well as the absence of ADR schemes in areas or industry sectors where they may be needed (DG SANCO, 2009, p. 39). According to Hodges (2012, p. 27), consumers and also businesses are more willing to resolve disputes through ADR than through court proceedings, but often confusion regarding consumer ADR may prevent its successful use, in particular in a cross border context. More than half of European consumers (56\%) bought something via Internet (TNT opinion \& social, 2011, p. 31), of which almost all (48\%) were more confident when ordering goods or services from sellers or providers in their own country then from those in other parts of EU (The Gallup Organization, 2011, p. 6).

This sector-specific and geographical gap has been addressed at the European level with two already quoted proposals of a directive and a regulation. Essentially, the need for EU action roots in the need to implement EU policies 
and priorities by designing one coherent model, which can be utilized and rolled-over by the national bodies and organizations for the consumer protection.

Such a model would have additional benefits. ADR procedures can deliver valuable information on types of claims, trends in businesses and their method of operation. In this sense, ADR can also serve as a part of the quality management system, reinforcing and improving virtuous behavior and consumer empowerment (Hodges, 2012, pp. 30-31). Hodges also noted that (Hodges et al. 2012b, p. 4)

"... if consumer ADR systems are appropriately designed, [they] also offer considerable regulatory possibilities through supporting high standards of behavior in markets. Some national consumer ADR systems are clearly realizing their considerable potential to deliver both increased consumer protection and behavioral consequences for markets and traders, with great efficiency, low cost, and swift results."

To avoid introducing large economic incentives for lawyers and judges that might result in unmerited litigation and abusive practices, many of the national models have deliberately been designed conservatively (Hodges, 2012, p. 14). Within the court system of several countries, mediation services are being offered by the courts. However, court services of this kind may have a limited capacity, and can involve disproportionate costs (Hodges et al., 2012a, p. 1). The need for an effective European approach implies formation of consumer ADR schemes that can transform the existing regulatory systems to fast and effective ADR or ODR systems (Hodges et al., 2012b, p. 4).

\subsection{A Model for National Consumer ADR Architecture}

Hodges, Benöhr and Creutzfeldt-Banda (2012, p. 1) have proposed two principles for the design of national consumer ADR architecture:

1. To maximize effective trade, and thereby minimize the number of C2B disputes, by providing expert, informed and reliable sources of consumer advice, from a small number of trusted and clearly identifiable bodies. There needs to be a unified national network of advice centers, linked to expert sectoral bodies.

2. To provide a similar structure of CADR, designed so that it is inherently more attractive to consumers and traders than the court system as a process for resolving small disputes involving applying established law to factual trading situations. Hence, it needs be more user-friendly, quicker, and cheaper than courts, as well as satisfying the essential requirements for any acceptable means of dispute resolution, such as independence, accuracy and consistency of outputs, and so on.

The claim should be submitted online and the case taken forward by proper consumer ADR entity, acting impartially and neutrally but providing swift 
feedback to the consumer and trader over possible settlement (mediation/ conciliation, provided by phone or online). In case no settlement is reached, a final and binding decision should be issued.

\section{Figure 1: Dispute Resolution Pyramid}

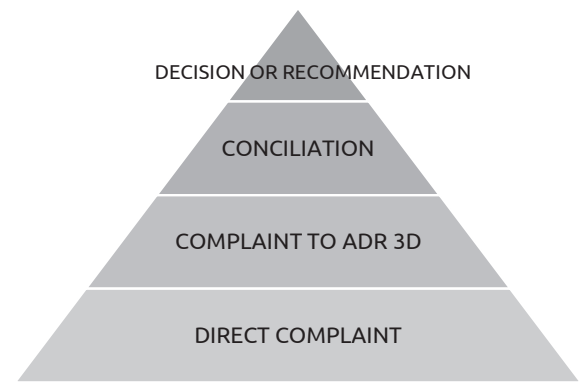

Source: Hodges et al., 2012d, p. 406

It is suggested that the outline of a national consumer ADR system should consist of several steps. The dispute resolution system should follow a simple sequence such as a) Consumer contacts the trader; b) Consumer contacts the Consumer ADR organization, or is referred to it by the trader; c) Consumer ADR organization tries to conciliate; $d$.) Consumer ADR makes a formal determination on the basis of a fair solution. In diagrammatic form as the integrated use of techniques by CADR provider, the consumer should start at the bottom of a pyramid structure (see Figure 1) (Hodges et al., 2012d, pp. 405-407):

\section{Figure 2: More sophisticated model of Dispute Resolution Pyramid}

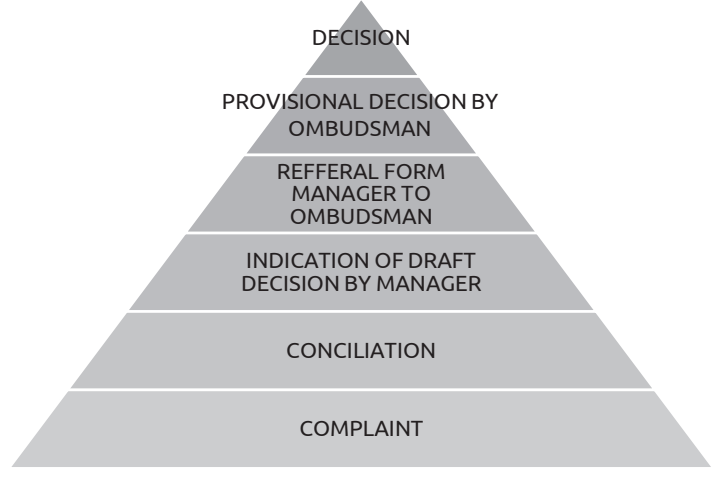

Source: Adopted after Hodges et al., 2012, p. 5

Many CADR models involve a sequence of techniques, starting with negotiation, then providing mediation, and ending with arbitration. In such a sequence the parties have sufficient opportunity to reconsider their positions, and hence agree on solutions. In some systems that give powers to a special body for complaints (e. g. to Ombudsman) the sequence of steps can 
even be extended. Here is such a "sophisticated" pyramid, with several steps that may lead to settlement rather than to submitting the dispute right away for a formal decisions (Hodges et al., 2012d, pp. 405-406).

\section{The Key Dilemmas Regarding Consumer ADR}

There are important dilemmas regarding consumer ADR that arise from major differences in national consumer ADR schemes. The consequence of national divergences may however be a convergence in compensatory collective redress in consumer matters across all Member States.

\subsection{Differences in Consumer ADR Schemes}

Directorate General for Health and Consumers (DG SANCO) has commissioned a number of studies on consumer ADR that have identified major divergences of the national ADR entities in terms of their sector specific and geographical coverage. On the basis of research conducted in 2009 (DG SANCO, pp. 8-30) there have been 750 ADR schemes identified in the Member States as relevant to business-to-consumer disputes, of which only $60 \%$ have been notified to the European Commission, but there were also 288 non-notified ADR schemes identified across the EU. Most of ADR schemes are available to consumers free of charge or at a reasonable price (below 50 EUR). Consumer disputes are usually resolved within a short time (in average 30-90 days). The procedure in consumer ADR may be entrusted to a collective body (e. g. a committee) or to an individual (a mediator or ombudsman). The result of the process may be very different - it may be a settlement, a non-binding recommendation or a binding decision. If binding, the decision may be binding only unilaterally (just for the trader) or bilaterally (for both parties). This means that practically every scheme of CADR is unique. The European Commission has developed a database of more than 400 ADR schemes (which makes only about $40 \%$ of the ADR entities), which they deem to be in conformity with the principles set up in the Commission Recommendations.

The research found that fourteen Member States ${ }^{19}$ have collective judicial mechanisms by which a group of consumers or a public interest representative may require compensation for the damage caused by unlawful conduct of the trader. Some other Member States plan to adopt such ADR systems by the end of 2015 (European Commission, 2011a, p. 5). ADR schemes for consumer disputes are broadly available in the financial services sector (payment services, consumer credit), and in telecommunication and transport services. In the energy sector they are still in the early developing stage. Essentially, some characteristics, such as compulsory membership, the binding nature of the decision and exchange of information within regulatory authorities, are more common in these sectors than in the others. The EU has taken initiatives

19 Austria, Bulgaria, Finland, France, Greece, Italy, Germany, Netherland, Poland, Portugal, Spain, Sweden and the United Kingdom (UK). 
to further promote development of common ADR schemes in these sectors (European Commission, 2012a, p. 6). The study of DG SANCO (2009, pp. 8-10) has also revealed the differences in the number of ADR bodies, the procedures (arbitration, mediation, etc.) and nature of the initiative (public or private).

Despite the existing diversity in consumer ADR schemes and models in the EU Member States, three types of host structures for consumer ADR systems can be broadly identified across different sectors and countries:

1. CADR agreements within public regulatory bodies (e.g. Germany, France, Lithuania and UK);

2. Independent decision-making bodies (e.g. Netherlands, Slovenia, Nordic, UK, and Germany);

3. Dispute Resolution arrangements sponsored by a trade association in order to resolve dispute arising under a code of business practice (e. $\mathrm{g}$. $(\mathrm{UK})^{20}$.

In the latest proposals, the objective of the European Commission is to improve the functionality of the common internal market and, more precisely, to increase the compensation for consumers and harmonize national legal regulations in terms of cross-border ADR schemes. To this end, the European Commission has set up three networks in order to facilitate consumer access to redress: FIN-NET (Network of ADR entities for financial services), the ECC-NET (European Consumer Centers), and SOLVIT ("online problem solving network"). But according to Juškys and Ulbaitè (2012, p. 27)

"... the official exchange between the ADR entities is also very low and mainly limited to the European Commission-sponsored mediation activities of the ECC-NET and FIN-NET. Such a situation may be explained by the fact that the Commission Recommendations have a non-binding character, and the Member States are free to decide on the model of consumer ADR at the national level."

\subsection{Convergence and Divergence in Collective Redress Mechanisms}

Collective redress and consumer ADR go hand in hand in a number of areas, in the court proceedings, in out-of-court mandatory procedures and in judicial/ voluntary agreement. According to Hodges (2012, p. 11), "... the interests of economy (e. g. bank charges, unfair commercial practice, medicine etc.) suggest that similar issues should be dealt with together, so as to achieve coherent, consistent and economical results." The most well-known "mass technique" of dispute resolution is the American class action, which has been extensively used in the USA since the 1960s. It is essential to note that class actions and other means of collective redress play a rather different role

20 Hodges et al., 2012d, p. 400. 
in different legal systems. The general role and status of collective redress in a particular country has important implications for a choice of available techniques. These divergences are reflected already in the evolution of terminology. The notion of "class actions" was abandoned in the European context in favor of the term "collective actions" and, by 2008, in favor of the notion of "collective redress"

In 2011 the European Commission carried out horizontal public consultations under the title "Towards a coherent European approach to collective redress". The aim was to identify common legal principles on collective redress and to examine how such common principles could fit into the EU legal system and into the legal orders of the $27 \mathrm{EU}$ Member States. Some features in which different forms of collective redress could help to better enforce EU legislation or protect the rights of EU citizens and businesses were explored as well.

The EC identified two forms of collective redress: 1. injunctive relief, whereby claimants seek to prevent the occurrence of illegal behaviour or its continuation; and 2. compensatory relief whereby damages are sought for the harm caused. These forms of collective redress can be obtained not only before the court. They may also be provided by the use of ADR mechanisms in the proceedings conducted by public or private representative entities (European Commission, 2013, pp. 3-4). According to an old but true statement of Mauro Cappelletti (Caponi, 2012, pp. 3-4), these efforts of the EU fit neatly in the original profile of the movement for access to justice, which is characterised inter alia by the movement to grant representation to collective interests and to protect them through such mechanisms as collective actions and granting consumers and associations standing to sue. Simplification of proceedings and the development of ADR methods, which is another feature of access to justice movement emphasized by Cappelletti, are also an element of the same policy.

Despite the existence of wide variation in consumer ADR schemes in most EU Member States (old and new), not all ADR schemes involve compensatory collective redress. About half of the Member States did not introduce collective redress at all. In fact, only UK, Netherlands, Germany, Spain, Poland and Sweden provide mechanisms for mass claims processing regarding securities. Other Member States have redress mechanism introduced in their Consumer Protection Act, but have very little practical implementation in practice (for example Croatia). See comparative analysis below (Table 2), which includes various premises on consumer collective redress through different ADR schemes in selected Member States.

21 Collective redress is a procedural mechanism that allows, for reasons of procedural economy and/or efficiency of enforcement, bundling of many similar legal claims into a single court action. Collective redress facilitates access to justice in particular in cases where the individual damage is so low that potential claimants would not think it worth pursuing an individual claim. It also strengthens the negotiating power of potential claimants and contributes to efficient administration of justice, by avoiding numerous proceedings concerning claims resulting from the same infringement of law. See European Commission, 2013 
Table 2: Comparative analysis of ADR schemes through compensatory collective redress for consumer matters in selected countries

\begin{tabular}{|c|c|}
\hline $\begin{array}{l}\text { CONSUMER ALTER- } \\
\text { NATIVE DISPUTE } \\
\text { RESOLUTION }\end{array}$ & $\begin{array}{l}\text { COURT PROCEE- } \\
\text { DINGS FOR SMALL } \\
\text { CLAIMS } \\
\text { Regulation } \\
\text { (861/2007) establishing } \\
\text { a European Small Claims } \\
\text { Procedure provides a } \\
\text { simplified court proce- } \\
\text { dure for cross border } \\
\text { claims under } 2,000 \text { EUR* }\end{array}$ \\
\hline \multicolumn{2}{|c|}{ The UNITED KINGDOM (UK) } \\
\hline $\begin{array}{l}\text { - } 43 \text { public in private } \\
\text { ADR schemes (e.g. } \\
\text { financial, Ombud- } \\
\text { sman, The office } \\
\text { Ombudsman for } \\
\text { Telecommunications } \\
\text { or Energy Ombud- } \\
\text { sman). } \\
\text { - DISADVANTAGES: } \\
\text { the transport sector. } \\
\text { Public financial ser- } \\
\text { vices ombudsman } \\
\text { in } 2009 \text {, dealt with } \\
\text { 160.000 cases. } \\
\text { - Duration of proce- } \\
\text { dure: } 31-90 \text { days. }\end{array}$ & $\begin{array}{l}\text { - The procedure for } \\
\text { small claims (less than } \\
€ 7.316 \text { ) and below } \\
€ 1500 \text { for personal } \\
\text { injury and irreparable } \\
\text { harm. } \\
\text { - Average duration of } \\
53 \text { weeks. ADR is not } \\
\text { mandatory. } \\
\text { - Jurisdiction under } \\
\text { Regulation is the dis- } \\
\text { trict, a higher court, } \\
\text { the court for small } \\
\text { claims, the Supreme } \\
\text { Court of Gibraltar.. }\end{array}$ \\
\hline
\end{tabular}

INJUNCTIONS Directive COMPENSATORY

98/27/ES o on injunctions COLLECTIVE REDRESS

for the protection of

consumers' interests**

(861/2007) establishing

a European Small Claims

Procedure provides a

simplified court proce-

claims under 2,000 EUR*

- Office of Fair Trading Three collective and the Relevant Con- redress mechanisms: sumer Associations 1. For competition injunction requiring cases

the court to stop the 2. Group Litigation illegal behaviour of Orders (GLO) allow traders.

- Prior consultation with the companies which are required. the court or individuals themselves to group together similar individual cases for harm suffered,

3. In cases where more than one person has the same interest, a mechanism through which a claim can be brought by one (or several) of these persons acting as a representative. The notion of "same interest" is interpreted quite restrictively.

\begin{tabular}{|c|c|c|c|}
\hline \multicolumn{2}{|l|}{ NETHERLAND } & \multirow[b]{2}{*}{$\begin{array}{l}\text { - Public authorities, all } \\
\text { bodies having a legal } \\
\text { capacity according } \\
\text { to the Dutch Consti- } \\
\text { tution, and the con- } \\
\text { sumer organization } \\
\text { Consumentenbond } \\
\text { may bring injunctive } \\
\text { actions. } \\
\text { - Consumentenbond } \\
\text { must try to reach an } \\
\text { out-of-court settle- } \\
\text { ment before seeking } \\
\text { an injunction before } \\
\text { the court. The Hague } \\
\text { Court is the only } \\
\text { competent court for } \\
\text { unfair contract terms. } \\
\text { The courts may order } \\
\text { penalty payments for } \\
\text { non-compliance and } \\
\text { the publication of } \\
\text { the judgment at the } \\
\text { expense of the losing } \\
\text { party. }\end{array}$} & \multirow[b]{2}{*}{$\begin{array}{l}\text { - Since 2005, in the } \\
\text { case of mass claims, } \\
\text { consumer organiza- } \\
\text { tions can reach an } \\
\text { agreement with the } \\
\text { trader and ask the } \\
\text { court to validate the } \\
\text { agreement. } \\
\text { - The system is an } \\
\text { opt-out system } \\
\text { and is based on the } \\
\text { willingness of the } \\
\text { parties to reach an } \\
\text { agreement. }\end{array}$} \\
\hline $\begin{array}{l}\text { - The Financial Servi- } \\
\text { ces Complaints Insti- } \\
\text { tute; The Advertising } \\
\text { Standard Authority; } \\
\text { The Foundation for } \\
\text { Consumer Complaint } \\
\text { Boards includes } 49 \\
\text { private commissions } \\
\text { which solve disputes } \\
\text { between consumers } \\
\text { and businesses. } \\
\text { - DISADVANTAGES: } \\
\text { in the investment } \\
\text { sector. } \\
\text { - The Foundation for } \\
\text { Consumer Complaint } \\
\text { Boards handled } \\
11.000 \text { cases in } 2008 . \\
\text { - The compliance } \\
\text { rate is very high: } \\
95,5 \% \text {, with } 100 \% \text { for } \\
\text { the Foundation for } \\
\text { Consumer Complaint } \\
\text { Boards. }\end{array}$ & $\begin{array}{l}\text { A small claims proce- } \\
\text { dure for claims under } \\
€ 5.000 \text { is available } \\
\text { in the Netherlands. } \\
\text { No appeal is possible } \\
\text { below } € 1.750\end{array}$ & & \\
\hline
\end{tabular}


Alternative Dispute Resolution for Consumer Cases: Are Divergences an Obstacle to Effective Access to Justice?

\begin{tabular}{l} 
GERMANY \\
\hline - Germany has more \\
than 200 public and \\
private ADR. They are \\
organized by profes- \\
sional organizations \\
and guilds. Some ADR \\
schemes operate at \\
local level; others \\
have a national cove- \\
rage. \\
- DISADVANTAGES: in \\
the energy, transport \\
and tourism sectors. \\
- Most of ADR cases \\
are solved within \\
30 to 90 days. On \\
average, the com- \\
pliance rate to ADR \\
decisions is $81 \%$.
\end{tabular}

A small claims procedure for claims under $€ 600$ is available in Germany. The court may, however, apply the ordinary procedure if the claim is too complex. Before going to court, parties must attempt in-court mediation. No appeal is possible, except in specific circumstances. $67,6 \%$ of the cases are dealt with within three months.
Qualified consumer organizations may seek injunctions before the courts. Negotiation before going to court is encouraged. Courts may order the publication of the judgment at the expense of the losing party. On average, injunction procedures take up to three years.

\section{Two different types of collective redress mechanisms:}

1. A test-case procedure in the area of financial investments. This opt-in procedure has two steps: 1 . The common factual and legal questions are decided in a test case procedure. 2. This

decision has to be applied to the individual cases. The procedure was introduced in 2005 for a period of five years and it is currently under review.

2. A representative action where consumers can assign their claims to a consumer organization which will bring the cases to court. This mechanism might either be used as a test-case procedure or a collective procedure in which claims are collected and the compensation granted by the court will be distributed among the consumers afterwards. However, in no case can the judgment be binding on persons who are not parties of the lawsuit.

\begin{tabular}{|c|c|c|c|}
\hline \multicolumn{4}{|l|}{ SPAIN } \\
\hline $\begin{array}{l}\text { - } 73 \text { public Consumer } \\
\text { Arbitration Boards } \\
\text { exist at different } \\
\text { levels. There are } \\
\text { also sector-specific } \\
\text { ADR schemes (e. g. } \\
\text { Association para la } \\
\text { Autorregulación de } \\
\text { la Communication } \\
\text { Commercial (AUTO- } \\
\text { CONTROL). } \\
\text { - DISADVANTAGES: } \\
\text { the financial services } \\
\text { and energy sectors. } \\
\text { - On average, com- } \\
\text { plaints are dealt with } \\
\text { within 30-180 days. }\end{array}$ & $\begin{array}{l}\text { - A small claims proce- } \\
\text { dure for claims under } \\
€ 30.000 \text { is available in } \\
\text { Spain. } \\
\text { - Appeal is possible } \\
\text { before the court of } \\
\text { first instance. This } \\
\text { procedure takes } \\
\text { approximately } 5 \\
\text { months. In-court } \\
\text { mediation is optional. }\end{array}$ & $\begin{array}{l}\text { The National Consu- } \\
\text { mer Institute and its } \\
\text { regional branches, the } \\
\text { public prosecutor and } \\
\text { qualified consumer } \\
\text { organizations may } \\
\text { seek injunctions } \\
\text { before the court. The } \\
\text { court can also order } \\
\text { the publication of } \\
\text { the judgment at the } \\
\text { expense of the losing } \\
\text { party. }\end{array}$ & $\begin{array}{l}\text { Spain has set up } \\
\text { an opt-in collective } \\
\text { redress action. } \\
\text { This action may be } \\
\text { initiated by consu- } \\
\text { mer organizations, } \\
\text { groups of victims and } \\
\text { legal entities legally } \\
\text { created to protect } \\
\text { consumers' interests. } \\
\text { Collective redress } \\
\text { actions can also be } \\
\text { taken when victims } \\
\text { are not individually } \\
\text { identified. Such action } \\
\text { may only be brought } \\
\text { by qualified consumer } \\
\text { organizations. Con- } \\
\text { sumer organizations } \\
\text { may advertise their } \\
\text { action through publi- } \\
\text { cation. The courts } \\
\text { of first instance and } \\
\text { commercial courts are } \\
\text { competent. }\end{array}$ \\
\hline
\end{tabular}




\begin{tabular}{|c|c|c|c|}
\hline SWEDEN & & & \\
\hline $\begin{array}{l}\text { - The public National } \\
\text { Board for Consumer } \\
\text { Complaints settles } \\
\text { disputes between } \\
\text { consumers and busi- } \\
\text { nesses. There are also } \\
\text { private sector-specific } \\
\text { Ombudsmen or com- } \\
\text { plaint boards (e. g. } \\
\text { the Committee for } \\
\text { Insurance of Persons, } \\
\text { the Complaint Board } \\
\text { of the Driving Schools } \\
\text { National Association, } \\
\text { the Disciplinary Board } \\
\text { of the Swedish Hotel } \\
\text { and Restaurant Asso- } \\
\text { ciation). } \\
\text { - The Public National } \\
\text { Board for Consumer } \\
\text { Complaints solves } \\
\text { disputes within } 6 \\
\text { months with a } 76 \% \\
\text { compliance rate. } \\
\text { On average, private } \\
\text { bodies deal with com- } \\
\text { plaints within three } \\
\text { months }\end{array}$ & $\begin{array}{l}\text { - A mandatory small } \\
\text { claims procedure } \\
\text { for pecuniary claims } \\
\text { under SEK } 19.7501 \\
\text { (approx. } 2.500 \text { ) is } \\
\text { available in Sweden. } \\
\text { Appeal to the decision } \\
\text { must be based on spe- } \\
\text { cific circumstances. } \\
\text { Small claims procedu- } \\
\text { res take } 2 \text { months. } \\
\text { - The District Courts } \\
\text { (tingsrätt) are compe- } \\
\text { tent to deal with the } \\
\text { Small Claims Regula- } \\
\text { tion. }\end{array}$ & $\begin{array}{l}\text { The Consumer } \\
\text { Ombudsman and qua- } \\
\text { lified consumer orga- } \\
\text { nisations may seek } \\
\text { injunctions before } \\
\text { the Market court. In } \\
\text { cross-border disputes } \\
\text { prior consultation is } \\
\text { mandatory before } \\
\text { taking action. The } \\
\text { Consumer Ombud- } \\
\text { sman also has direct } \\
\text { injunction powers. } \\
\text { All decisions of the } \\
\text { Consumer Ombud- } \\
\text { sman and judgements } \\
\text { of the Market Court } \\
\text { are published. The } \\
\text { average duration of } \\
\text { an injunction proce- } \\
\text { dure is six months. }\end{array}$ & $\begin{array}{l}\text { - Consumer com- } \\
\text { pensatory collective } \\
\text { redress has been } \\
\text { available in Sweden } \\
\text { since } 2003 \text { through an } \\
\text { opt-in group action. } \\
\text { This action can be } \\
\text { initiated by private } \\
\text { individuals, consumer } \\
\text { organisations or a } \\
\text { government-appoin- } \\
\text { ted authority. In six } \\
\text { years, twelve cases } \\
\text { were brought before } \\
\text { the court. In } 2008 \text {, the } \\
\text { procedure was positi- } \\
\text { vely evaluated. } \\
\text { - The Swedish } \\
\text { Ombudsman initiated } \\
\text { an action against an } \\
\text { energy supplier. The } \\
\text { company failed to } \\
\text { supply electricity to } \\
7.000 \text { consumers at } \\
\text { the price agreed in } \\
\text { the contract. The case } \\
\text { is still pending. }\end{array}$ \\
\hline
\end{tabular}
months.

\begin{tabular}{|c|c|c|c|}
\hline \multicolumn{4}{|l|}{ POLAND } \\
\hline $\begin{array}{l}\text { - } 31 \text { permanent } \\
\text { Consumer Arbitration } \\
\text { Courts offer arbi- } \\
\text { tration. The Trade } \\
\text { inspectorate runs } \\
\text { mediation schemes. } \\
\text { - There are some } \\
\text { sectoral ADR schemes } \\
\text { (e. g. the Insurance } \\
\text { Ombudsman (a public } \\
\text { body) or the Banking } \\
\text { Ombudsman (a } \\
\text { private body). } \\
\text { - DISADVANTAGES: } \\
\text { particular in the } \\
\text { investment, transport } \\
\text { and tourism, energy } \\
\text { and telecommunica- } \\
\text { tion sectors. } \\
\text { - The average duration } \\
\text { of ADR proceedings is } \\
\text { between one to three } \\
\text { months. }\end{array}$ & $\begin{array}{l}\text { A specific mandatory } \\
\text { small claims proce- } \\
\text { dure for claims under } \\
\text { PLN } 10.000 \text { (€2.500) } \\
\text { exists. Its scope is } \\
\text { limited to contractual } \\
\text { claims, claims arising } \\
\text { from a commercial } \\
\text { guarantee or from } \\
\text { non-conformity of } \\
\text { goods and claims for } \\
\text { payment resulting } \\
\text { from contracts for } \\
\text { lease of apartments. } \\
\text { Appeals are restricted } \\
\text { to error of law or } \\
\text { violation of procedu- } \\
\text { ral rules. }\end{array}$ & $\begin{array}{l}\text { - The President of the } \\
\text { Office for Competi- } \\
\text { tion and Consumer } \\
\text { Protection has direct } \\
\text { injunction powers. } \\
\text { Qualified consumer } \\
\text { organizations and } \\
\text { individual consumers } \\
\text { can seek injunctions } \\
\text { before the President } \\
\text { of the Office for Com- } \\
\text { petition and Consu- } \\
\text { mer Protection. } \\
\text { - The decisions of } \\
\text { the President can be } \\
\text { appealed before the } \\
\text { Court for Competition } \\
\text { and Consumer Protec- } \\
\text { tion in Warsaw. } \\
\text { - For unfair contract } \\
\text { terms, consumer orga- } \\
\text { nizations, individual } \\
\text { consumers, the Pre- } \\
\text { sident of the Office } \\
\text { for Competition and } \\
\text { Consumer Protection, } \\
\text { a local consumer } \\
\text { Ombudsman can seek } \\
\text { an injunction directly } \\
\text { before the Court } \\
\text { for Competition and } \\
\text { Consumer Protection } \\
\text { in Warsaw. The court } \\
\text { can declare a contract } \\
\text { term unlawful "erga } \\
\text { omnes". }\end{array}$ & $\begin{array}{l}\text { A new action for con- } \\
\text { sumer compensatory } \\
\text { collective redress } \\
\text { entered into force in } \\
\text { July } 2010 \text {. } \\
\text { The action can be } \\
\text { taken by at least } 10 \\
\text { claimants or regional } \\
\text { Ombudsmen. It is an } \\
\text { opt-in system. }\end{array}$ \\
\hline
\end{tabular}


Alternative Dispute Resolution for Consumer Cases: Are Divergences an Obstacle to Effective Access to Justice?

\begin{tabular}{|c|c|c|c|}
\hline \multicolumn{4}{|l|}{ LATVIA } \\
\hline $\begin{array}{l}\text { - Three ADR schemes: } \\
\text { one public scheme, } \\
\text { the Consumer Rights } \\
\text { Protection Centre, } \\
\text { and two private, } \\
\text { the Ombudsman of } \\
\text { the association of } \\
\text { commercial banks and } \\
\text { the Ombudsman of } \\
\text { the association of the } \\
\text { Latvian insurers. } \\
\text { - DISADVANTAGES: } \\
\text { investments, postal } \\
\text { services and energy } \\
\text { sectors. Duration: } \\
\text { 31-90 days. }\end{array}$ & $\begin{array}{l}\text { It does not have a } \\
\text { specific or simplified } \\
\text { small claims proce- } \\
\text { dure for national } \\
\text { claims. } \\
\text { Ordinary court proce- } \\
\text { dure applies to small } \\
\text { claims. }\end{array}$ & $\begin{array}{l}\text { The Consumer Rights } \\
\text { Protection Centre } \\
\text { has direct injunction } \\
\text { powers. Qualified } \\
\text { consumer associations } \\
\text { may seek injunctions } \\
\text { before the Consumer } \\
\text { Rights Protection } \\
\text { Centre. Its decisions } \\
\text { are binding on the } \\
\text { traders, who can } \\
\text { appeal to the Ministry } \\
\text { of Economics and } \\
\text { then to the Admini- } \\
\text { strative Court. The } \\
\text { Centre may publish } \\
\text { the decision. Injuncti- } \\
\text { ons procedures take } \\
\text { one to four months. }\end{array}$ & $\begin{array}{l}\text { No mechanism of } \\
\text { compensatory collec- } \\
\text { tive redress exists. }\end{array}$ \\
\hline \multicolumn{4}{|l|}{ LITHUANIA } \\
\hline $\begin{array}{l}\text { - The Consumer Rights } \\
\text { Protection Authority } \\
\text { can deal with all } \\
\text { consumer disputes. } \\
\text { The Communications } \\
\text { Regulatory Authority } \\
\text { and the Insurance } \\
\text { Supervisory Commis- } \\
\text { sion are sector speci- } \\
\text { fic ADR schemes. } \\
\text { - In } 2008, \text { the Consu- } \\
\text { mer Rights Protection } \\
\text { Authority handled } \\
\text { complaints within one } \\
\text { month with a } 52 \% \\
\text { compliance rate. }\end{array}$ & $\begin{array}{l}\text { - A mandatory specific } \\
\text { small claims proce- } \\
\text { dure for claims under } \\
\text { LTL } 1.000 \text { (€ } 289 \text { ) is } \\
\text { available. } \\
\text { - No appeal is possible } \\
\text { below LTL } 250 \text { (€ } 72) \text {, } \\
\text { except for some } \\
\text { matters. The average } \\
\text { duration of this small } \\
\text { claims procedure is } \\
\text { one to three months. } \\
\text { Prior in-court media- } \\
\text { tion is obligatory. }\end{array}$ & $\begin{array}{l}\text { The National Consu- } \\
\text { mer Rights Protection } \\
\text { Authority has direct } \\
\text { injunction powers. } \\
\text { In case of non-com- } \\
\text { pliance, the National } \\
\text { Consumer Rights } \\
\text { Protection Board may } \\
\text { bring the case before } \\
\text { the court. Qualified } \\
\text { consumer organizati- } \\
\text { ons may seek injunct- } \\
\text { ons before the court. } \\
\text { The court may order } \\
\text { the publication of } \\
\text { the judgment at the } \\
\text { expense of the losing } \\
\text { party. Case of ADR: } \\
\text { Bank had unexpec- } \\
\text { tedly increased the } \\
\text { interest rate of credit } \\
\text { cards by } 5 \text { \%, without } \\
\text { informing each consu- } \\
\text { mer individually. } \\
\text { FINE: } 5 \text {.792 }\end{array}$ & $\begin{array}{l}\text { No mechanism of } \\
\text { compensatory collec- } \\
\text { tive redress exists. }\end{array}$ \\
\hline
\end{tabular}




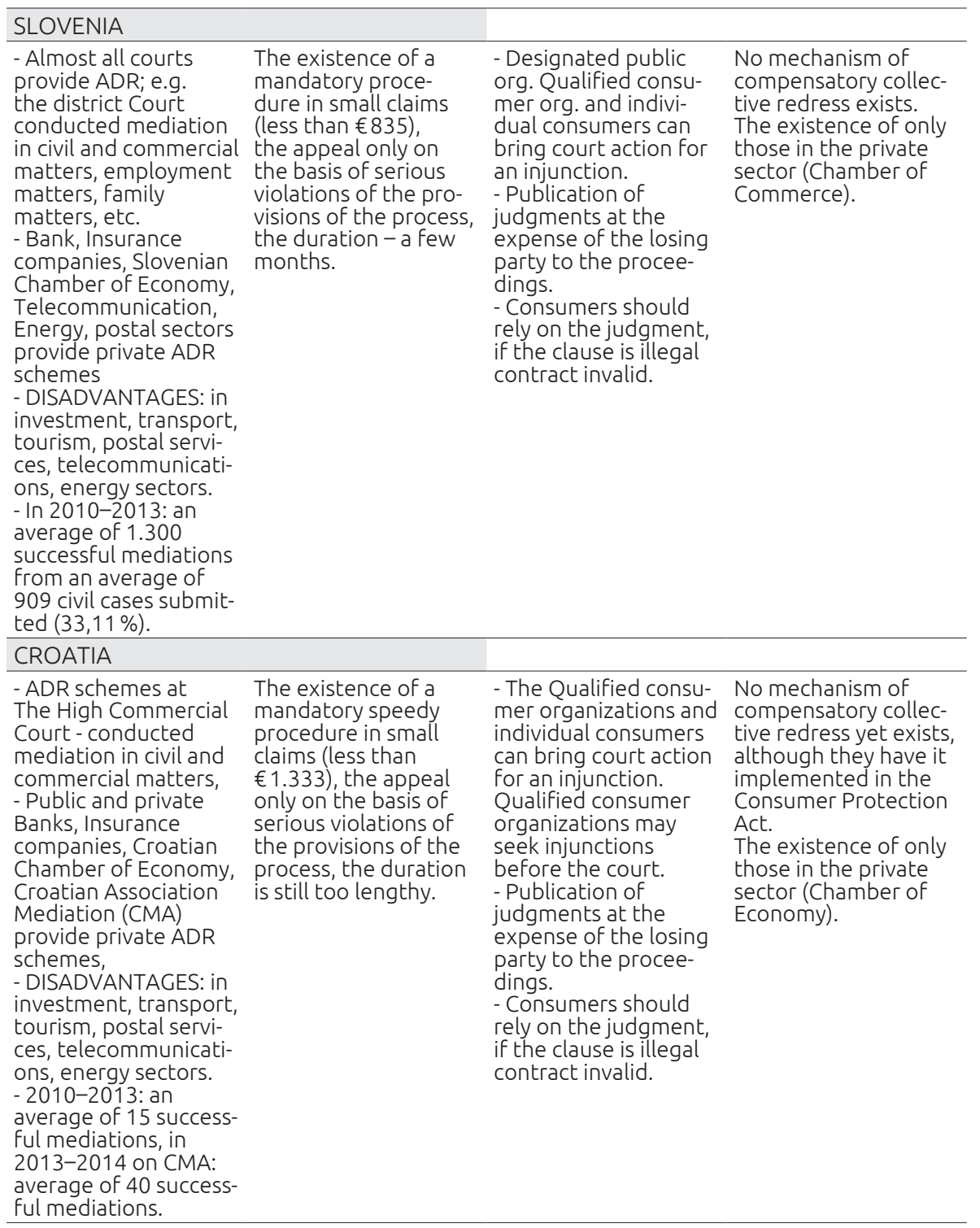

Source: Adopted after European Commission (Consumer redress, 2012), Hodges (2012), Manual reports of the Supreme Court of the RS (2009-2013), Manual reports of the High Commerce Court RH (2006-2013), Croatian Association Mediation (2013-2014) and authors own. 
Another difference in approach relates to the way in which represented groups are composed. In this aspect, two models have raised considerable interest in the debates: "opt-in"22 and "opt-out"23 model. According to European Commission (2013, p. 11):

"In the "opt-in" model, the judgment is binding on those who opted in, while all other individuals potentially harmed by the same or similar infringement remain free to pursue their damages claims individually. Conversely, in the "opt-out" model, the judgment is binding on all individuals that belong to the defined group except for those who explicitly opted out. The "opt-in" model is used by most Member States that provide for collective redress. The "opt-out" model is used in Portugal, Bulgaria and the Netherlands (in collective settlements) as well as in Denmark in clearly defined consumer cases brought as representative actions."

Another issue of controversy is organizational - which qualified authority could provide the most efficient method of the mass claims processing. In this respect, one of the reasons why only $40 \%$ ADR schemes were reported to the EU may be inconsistency of ADR entities with the European legislation (see infra about this problem in Slovenia and Croatia).

In order to develop a common framework, the EU institutions have identified particular issues to be addressed in developing a European horizontal framework for collective redress. Taking into account the complexity on the one hand and the need to ensure a coherent approach to collective redress on the other hand, the Commission issued a recommendation on collective redress. That recommendation is based on Article 292 TFEU that suggests horizontal common principles of collective redress in the European Union which should be complied with by all Member States. After adoption and publication of the Commission Recommendation, the Member States should be given two years to implement the principles recommended by the Recommendation in national collective redress systems (European Commission, 2013, p. 16).

\section{The Main Differences of Consumer ADR in Slovenia and Croatia}

Both Slovenia and Croatia started to develop ADR practices and consumer dispute resolution from the early 2000's. One of the motives for the introduction of ADR schemes was in both Member States the implementation of EU legislation. The ADR was promoted in different sectors, both public and private. General ADR procedures were introduced in the courts of law, but more specific ADR schemes were launched in the specific sectors for specific

22 The group includes only those individuals or legal persons who actively opt in to become part of the represented group.

23 The group is composed of all individuals who belong to the defined group and claim to have been harmed by the same or similar infringement unless they actively opt out of the group. 
users and services, such as banks and insurance, telecommunication, payment and other services. However, the use of these arrangements is still limited. What may be striking, given their similar history, tradition, and legal culture is that CADR options in Croatia and Slovenia have developed in a rather different manner. In the table below, some main differences regarding consumer ADR procedures in Slovenia and Croatia are highlighted.

Table 3: The main differences in the area of consumer ADR in Slovenia and Croatia

\begin{tabular}{|c|c|c|}
\hline $\begin{array}{l}\text { Factors for } \\
\text { differences } \\
\text { in Consumer } \\
\text { ADR } \\
\text { proceedings }\end{array}$ & SLOVENIA & CROATIA \\
\hline $\begin{array}{l}\text { Consumer } \\
\text { ADR schemes }\end{array}$ & $\begin{array}{l}\text { Mediation, Conciliation, } \\
\text { Arbitration }\end{array}$ & $\begin{array}{l}\text { Mediation, Conciliation, } \\
\text { Arbitration }\end{array}$ \\
\hline $\begin{array}{l}\text { Consumer } \\
\text { ADR entities }\end{array}$ & $\begin{array}{l}\text { Public ADR entities: All courts, } \\
\text { regulatory agencies, telecommu- } \\
\text { nication, energy, postal, emplo- } \\
\text { yers' and health services. } \\
\text { Private ADR entities: Association } \\
\text { of Banks and Insurance Councils, } \\
\text { Slovenian Chamber of Commerce, } \\
\text { Slovenian Mediators' Association, } \\
\text { employers organizations, private } \\
\text { mediation organizations and } \\
\text { institutes }\end{array}$ & $\begin{array}{l}\text { Public ADR entities: High Com- } \\
\text { mercial Court, five commercial } \\
\text { courts, County Court in Zagreb, } \\
\text { eight municipal courts, County } \\
\text { Court in Zagreb. } \\
\text { Private ADR entities: Banks and } \\
\text { Insurance Bureaus, Croatian } \\
\text { Mediation Association, Croatian } \\
\text { Chamber of Economy, Croatian } \\
\text { Chamber of Trades and Crafts, } \\
\text { Croatian Bar Association, private } \\
\text { consumer organizations and } \\
\text { institutes. }\end{array}$ \\
\hline $\begin{array}{l}\text { Legislation } \\
\text { on consumer } \\
\text { ADR }\end{array}$ & $\begin{array}{l}\text { The main ADR acts: Civil Proce- } \\
\text { dure Act, Act on Mediation in Civil } \\
\text { and Commercial Matters, Alterna- } \\
\text { tive Legal Dispute Resolution Act, } \\
\text { Proposal of Consumer Alternative } \\
\text { Dispute Resolution Act (2014), } \\
\text { Arbitration Law. } \\
\text { The sectorial Acts: Law on Consu- } \\
\text { mer Protection, Energy Law, Elec- } \\
\text { tronic Communication Act, Labor } \\
\text { Relations Act, Administrative } \\
\text { Procedure Act (article 137), Law } \\
\text { on Patients' Rights, etc. }\end{array}$ & $\begin{array}{l}\text { The main ADR acts: Code of Civil } \\
\text { Procedure, Mediation Act, Arbitra- } \\
\text { tion Law. } \\
\text { The sectorial Acts: Law on Consu- } \\
\text { mer Protection, Family Act (2014), } \\
\text { Administrative Procedure Act } \\
\text { (article 57), etc. }\end{array}$ \\
\hline $\begin{array}{l}\text { Consumer } \\
\text { ADR } \\
\text { proceedings }\end{array}$ & $\begin{array}{l}\text { Administrative and civil } \\
\text { proceedings }\end{array}$ & Mostly civil proceedings \\
\hline $\begin{array}{l}\text { Parties in } \\
\text { CADR } \\
\text { proceedings }\end{array}$ & $\begin{array}{l}\text { Public or private authorities } \\
\Leftrightarrow \text { legal or natural persons; } \\
\text { legal or natural persons }\end{array}$ & Legal and natural persons \\
\hline $\begin{array}{l}\text { Legal nature } \\
\text { of } \\
\text { relationship } \\
\text { in CADR }\end{array}$ & $\begin{array}{l}\text { General public law obligations; } \\
\text { individual public law relationship, } \\
\text { individual contract relationship. }\end{array}$ & $\begin{array}{l}\text { Individual contractual relationship } \\
\text { of private law nature } \\
\text { (erga omnes, inter partes, interme- } \\
\text { diate). }\end{array}$ \\
\hline
\end{tabular}




\begin{tabular}{|c|c|c|}
\hline $\begin{array}{l}\text { Legal nature } \\
\text { of decision- } \\
\text {-making in } \\
\text { CADR } \\
\text { proceedings }\end{array}$ & $\begin{array}{l}\text { Authoritative or relative/exclu- } \\
\text { sive, consensual decision making } \\
\text { on the matter (regulation based } \\
\text { on the will and interests of the } \\
\text { parties or just on the will and } \\
\text { interests of one party). }\end{array}$ & $\begin{array}{l}\text { Relative/exclusive, consensual } \\
\text { regulation (regulation based } \\
\text { on the will and interests of the } \\
\text { parties). }\end{array}$ \\
\hline $\begin{array}{l}\text { Types of legal } \\
\text { relationships } \\
\text { in CADR } \\
\text { proceedings }\end{array}$ & $\begin{array}{l}\text { G2C/C2G, G2G, G2B, B2B, } \\
\text { B2C/C2B } \\
\text { (G: government; } \\
\text { B: business, but also PSO; } \\
\text { C citizen/ consumer/customer). }\end{array}$ & $\begin{array}{l}\text { B2B, B2C, C2C, C2B } \\
\text { (B and C are private parties). }\end{array}$ \\
\hline $\begin{array}{l}\text { Protected } \\
\text { interests in } \\
\text { CADR } \\
\text { proceedings }\end{array}$ & Both public and private interests. & Mainly private interests. \\
\hline $\begin{array}{l}\text { Legal status } \\
\text { of the parties } \\
\text { involved in } \\
\text { CADR }\end{array}$ & $\begin{array}{l}\text { Negative, positive, active or } \\
\text { passive status of natural person } \\
\text { and also (non)transferable perso- } \\
\text { nal status (universal). }\end{array}$ & $\begin{array}{l}\text { Non-transferable (personal } \\
\text { relationship), transferable } \\
\text { (singular / universal). }\end{array}$ \\
\hline $\begin{array}{l}\text { Legal con- } \\
\text { sequences of } \\
\text { the } \\
\text { settlement in } \\
\text { CADR } \\
\text { proceedings }\end{array}$ & $\begin{array}{l}\text { - in administrative CADR procee- } \\
\text { dings: non-binding for consumers } \\
\text { (appeal right to administrative } \\
\text { court) and binding for traders. } \\
\text { - in civil CADR proceedings: } \\
\text { binding for both parties, in case } \\
\text { of un-fulfillment of obligations- } \\
\text { right for an appeal on the regular } \\
\text { Courts. }\end{array}$ & $\begin{array}{l}\text { Binding for both parties involved; } \\
\text { in case of un-fulfillment of obliga- } \\
\text { tions - right to request immediate } \\
\text { enforcement or (for non-enforce- } \\
\text { able settlements) to initiate pro- } \\
\text { ceedings in the courts of general } \\
\text { jurisdiction. }\end{array}$ \\
\hline
\end{tabular}

As presented in the table above, general consumer ADR schemes are almost the same in both countries, although they are carried out by different ADR entities.

Some experiments in introducing ADR at Slovenian court system date back to late 1990s (Galič in Hodges et al., 2012c, p. 197), while development of ADR legislation and introducing ADR in Croatian courts took place in the 2000s (see e. g. Mediation Act 2003; Croatian Phare project on introduction of court-annexed mediation in Croatian courts, 2005-2009) ${ }^{24}$. According to Galič (ibid.) Slovenian litigation practice in spite of all reforms still displays delays and weaknesses. The court cases last long and involve costs and a loser-pays risks. Therefore, business organizations in Slovenia established mediation schemes in Slovenia fairly early, in the beginning of 2000s. Some of them were Chamber of Commerce (which had its well-established Arbitration and Mediation Centre), the Employers' Organization (which offered mediation and arbitration within the Centre for Business Services), the Chamber of Enterprises, the Banks Association and the Insurers Association, and the Slovenian Conciliation Council ${ }^{25}$. In Croatia formation of private mediation

24 More about the Phare project on http://www.mirenje.hr/index.php/o-nama/openite-informacije.html and http://www.vtsrh.hr/index.php?page=conciliation\&lang=hr

25 The latter was not overly active, as in 2011, there were just 26 cases submitted to the Conciliation Council, and in just two of those cases a settlement was reached (see Galič in Hodges et al. 2012c, p. 197). 
services started a bit later, but the providing organizations were similar (see Uzelac et al., 2010).

Until 2012, in Slovenia, if no consensual settlement was reached by mediation, a reasoned decision could be issued as non-binding recommendation for both parties. But after an amendment to ADR legislation, mediation institutions are no longer authorized to issue non-binding decisions. This has had a negative impact on the practical importance of the ADR scheme (Galič in Hodges et al., 2012c, p. 197). In Croatia, issuing non-binding recommendations and decisions is generally not prohibited (if not expressly excluded by the parties' agreement). On the other hand, mediated settlements are in principle binding. However, the ability to directly enforce them depends on whether mediation was conducted by the court or by a private mediation organization. If settlement is reached in a court-annexed scheme, the settlement is generally regarded to have to force of a court-negotiated settlement (sudska nagodba) which is directly enforceable. In spite of legal provisions that wanted to give the same effect to the settlement reached before private ADR organizations, in practice these settlements experience difficulties in their enforcement (new legislative plans that should address this situation are underway).

Voluntary mediation schemes now exist in all Slovenian courts and are generally successful. On the other hand, in Croatia voluntary mediation is offered as a service in only some courts, such as High Commercial Court, five commercial courts, eight municipal courts and one county court. In Slovenia ADR is regulated by Civil Procedure Act, Act on Mediation in Civil and Commercial Matters and Alternative Legal Dispute Resolution Act - the latter providing that all courts must offer mediation or another ADR method (Galič \& Hodges in Hodges et al., 2012c, p. 202).

\section{Figure 3: Statistics of court-annexed mediation in Slovenia}

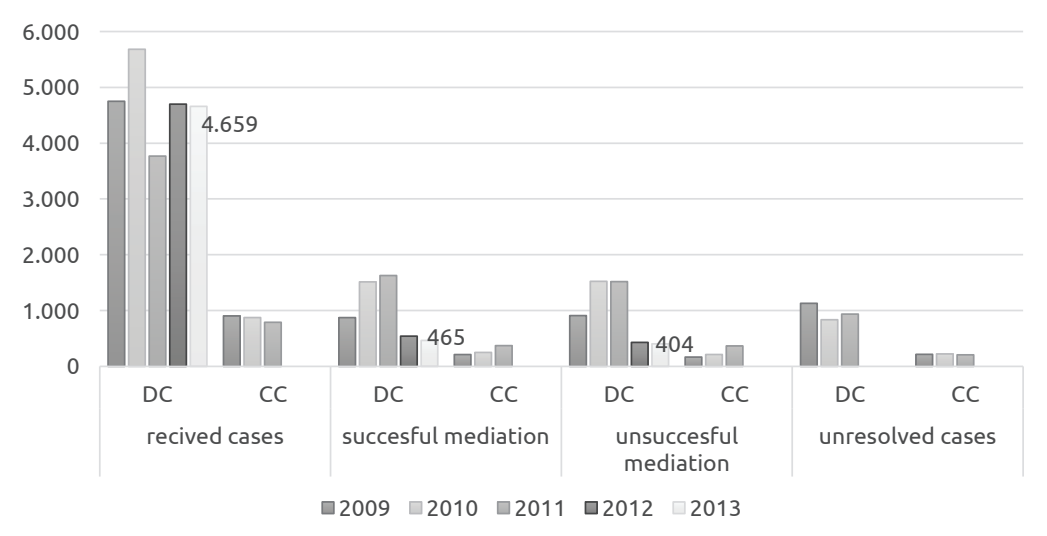

Source: Reports on mediation before the District and County Court for 2009-2013 
In Slovenian district courts in average 4711 mediation cases were submitted in the last five years. Almost $50 \%$ of them were successfully resolved by court-annexed mediation ${ }^{26}$ (see Figure 3). Yet, the rest - i. e. $90 \%$ of all civil litigation cases - or in average 123.086 cases on district courts and 525.114 cases in county courts ${ }^{27}$, are resolved by court adjudication (see Figure 4).

\section{Figure 4: Statistics of resolving civil litigation cases in Slovenia}

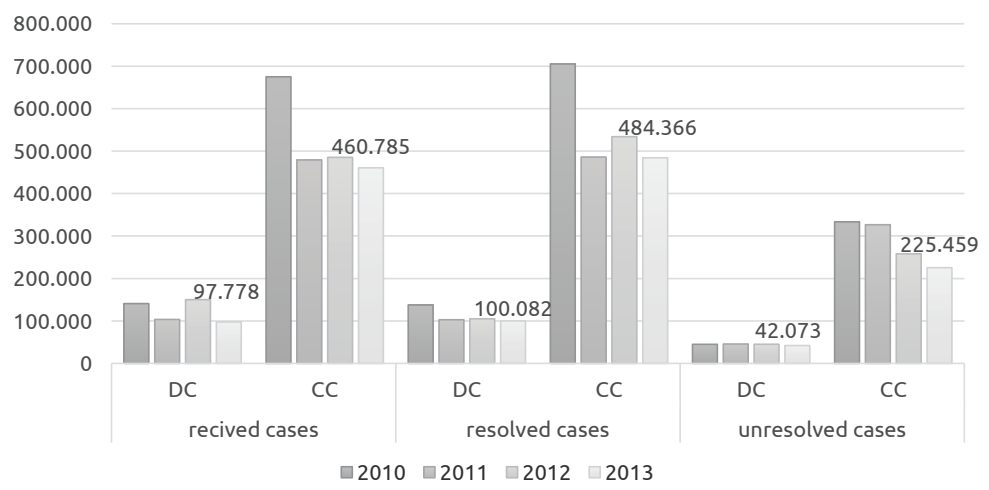

Source: Reports of the district (DC) and county courts (CC) for 2010-2013

\section{Figure 5: Statistics of resolving civil litigation cases in Croatia}

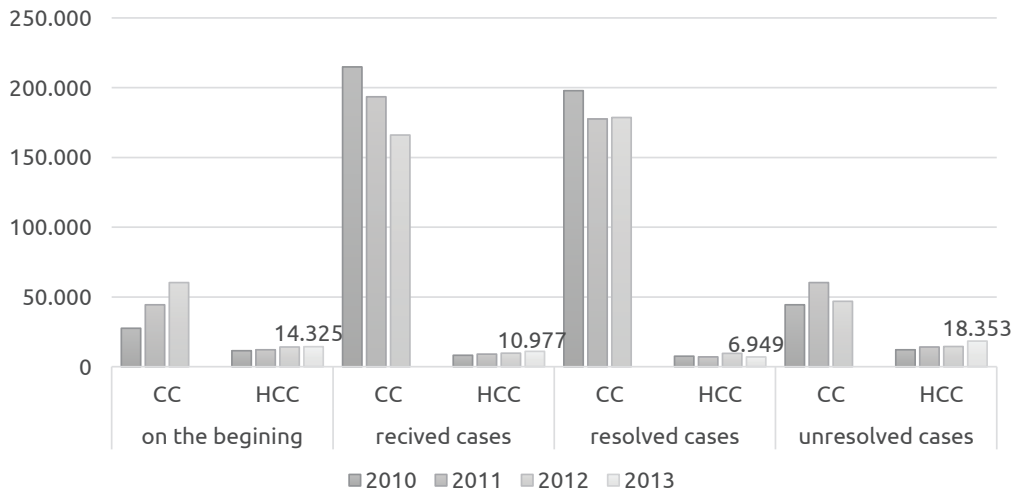

Source: Manual reports of the High Commercial Court (HCC) and the Commercial Court (CC) for 2010-2013

26 Reports of the Slovenian Supreme Court (2010-2013); Statistical reports for mediation cases at the District and County Courts for 2009-2013

27 For example in 2010 there were 15.202 unsolved civil litigation cases (1. 1. 2010), 4.256 of those cases were solved and 3.864 new cases had appeared, so there are still 14.770 unsolved cases left (31. 12. 2010). In the same year there were 875 cases submitted to mediation procedure, 350 of those cases were as successful mediations, 213 were unsuccessful mediation cases and 405 resolved cases with other legal frameworks. 
Figure 6: Statistics of court-annexed mediation in Croatia

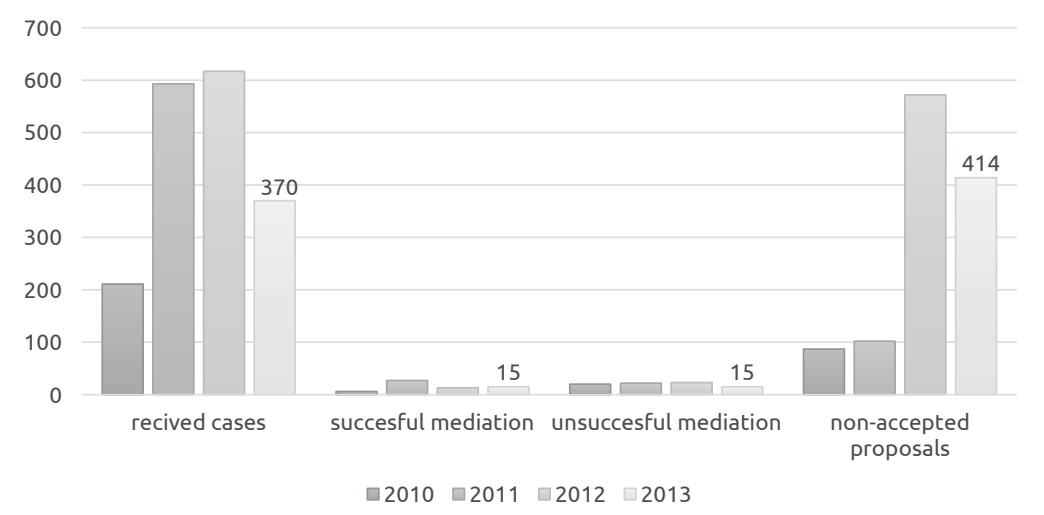

Source: Reports on mediation in the High Commercial Court (HCC) for 2010-2013

In Croatia, in spite of the early adoption of mediation legislation and the frequent polishing of the normative framework, there was no sufficient support for introduction of mediation schemes in all courts. The Croatian High Commercial Court from 13.000 civil litigation cases in average resolves 7.747 cases per year (see Figure 5). At the same Court there are in average 448 submitted mediation proposals per year, of which almost $60 \%$ are not accepted. That is why in average only about 15 mediation cases are successfully resolved per year at that court ${ }^{28}$ (see Figure 6).

In Croatia, a significant part of potential users still do not know about existence of ADR mechanisms. A lot of attention has been lately given to promotion of the ADR mechanisms, but so far without great results. It seems that in both Balkan countries, according to general observations, population prefers to use courts as authoritative decision-makers. There is also still the lack of consumers' awareness about availability of ADR procedures. In Slovenia, main consumer protection is provided to consumers within the Consumer Protection Office/Inspectorate ${ }^{29}$. Its functions are recently assumed by the Ministry of the Economic Development and Technology. The Slovenian Consumer Inspectorate is by its caseload similar to the Croatian High Commercial Court (see figure 6) and can help consumers who experience problems with goods or services by contacting their sellers, but according to Galič (in Hodges et al. 2012c, p. 199) there is no ADR mechanism under which trade associations might assist in responding to complaints and there are no ombudsmen for consumer-to-business disputes.

28 Reports of the High Commercial Court and Commercial Court for 2010-2013.

29 See Tržni Inšpektorat RS on http://www.ti.gov.si/en/ 


\section{Figure 7: Comparison of HCC cases in Croatia and CPI cases in Slovenia}

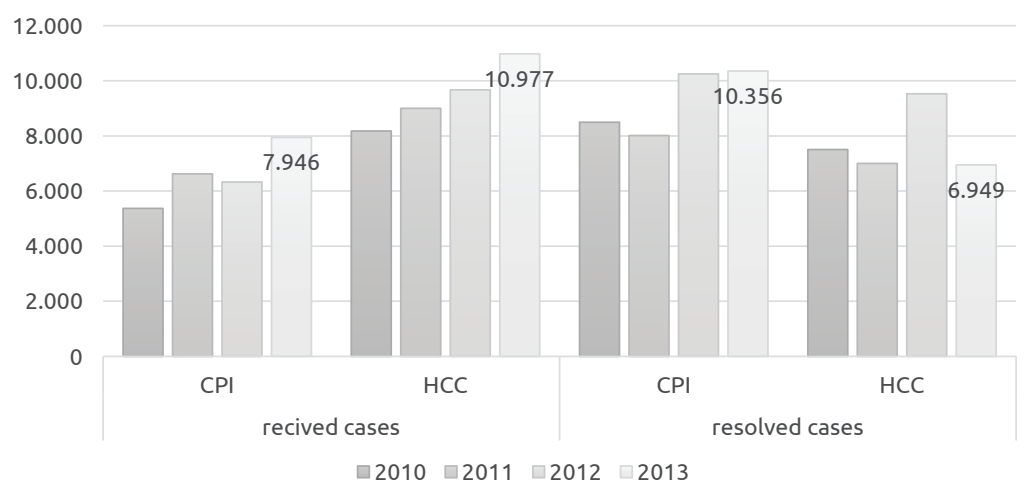

Source: Manual reports of the Consumer Protection Inspectorate for 2010-2013

Additionally, the general view is that the Slovenian Consumer Protection Inspectorate has been ineffective ${ }^{30}$. Consumers can also contact the Slovenian Consumer Association ${ }^{31}$, which hosts the ECC - Net Office for Slovenia, although its jurisdiction is only for cross-border claims. According to Galič (in Hodges et al., 2012c, p. 201), the ECC Slovenia Office has promoted ADR through media appearances and organized meetings, which seek to affect public opinion in general and in relation to specific traders, but coercive powers can only be exercised where cases are referred to the courts or a governmental Inspectorate. The experience of the Human Rights Ombudsperson and also the courts shows that if an independent dispute resolution body has no effective power, business (or government) will not pay attention to its suggestions, and consumers will not seek to use it.

Both Member States have different Agencies which deal with consumers ${ }^{32}$ and act as independent regulatory bodies. They can conduct administrative proceedings and issue administrative decisions, which are subject to judicial review in the administrative courts.

But, while in Croatia various regulatory agencies do not engage in mediation and other ADR schemes, under Slovenian law ${ }^{33}$ such agencies may conduct mediation/conciliation proceedings, aiming to reach a consensual solution between parties in dispute. As Galič (in Hodges et al., 2012c, p. 198) noted, proceedings must be in accordance with the principles of impartiality, equality, equity and confidentiality. The ADR mechanism at regulatory agencies in

30 The Consumer Protection Office receives almost 5000 requests per year for assistance in the complaint that are resolved only by forwarding it to other competent bodies.

31 See Zveza potrošnikov Slovenije on http://www.zps.si/o-nas/english/3.html?ltemid=697. Annual membership fee is 40 EUR, and members get free legal advice, a monthly magazine and a mediation facility.

32 For example these are Agency for postal and electronic telecommunications of the Republic of Slovenia (RS), Energy Agency of the RS, Securities Market Agency, etc.

33 See the Law on electronic communications (Art. 63, 119; OJ RS, No. 13/2007); the Energy Law (OJ RS, No.27/2007); the Law on Security Market (Art. 387a, OJ RS, No. 51/2006). 
Slovenia is open to all parties, not only for consumer disputes. The problem is that for example the Law on Electronic Communication unclearly defines the relationship between such ADR procedure and matters in which the competent agency conducts administrative proceedings. Essentially, the Agency can conduct mediation/conciliation proceedings in all disputes between parties, concerning rights arising from the law. For example Agency for postal and electronic communication (APEC) receives in average 702 cases, of which almost $50 \%$ (334) are successfully resolved with conciliation, but another $50 \%$ (265) come out as administrative decision, of which almost half (107) аге negative and parties can appeal (see Figure 8). However, if conciliation does not result in a settlement, the Agency has jurisdiction to decide a dispute by its decrees, unless one of the parties has already brought the case to the regular court. If the Agency comes with its decision first, the losing party can appeal to Administrative Court, irrespective of the fact that disputed matter is within jurisdiction of civil courts. According to Galič (2012, p. 6), the use of ADR schemes in Slovenia is inadequate, misguided and unconstitutional, particularly in the most critical sectors like financial services, postal and telecommunication services and in the energy sector.

\section{Figure 8: Statistics of Agency-annexed conciliation in Slovenia}

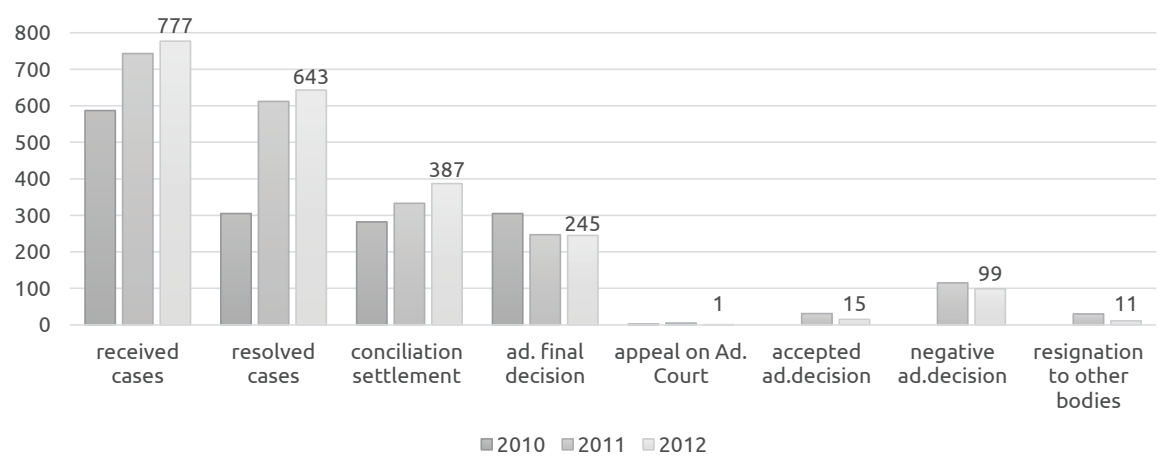

Source: Manual reports of the Agency for Postal and Electronic Communications for 2010-2012

Essentially, an effective, certified ADR system for consumer protection cases exists in neither Slovenia nor Croatia. Governmental and non-governmental organizations which are concerned with this particular field should be jointly responsible for raising the awareness of national consumers and consumers from other Member States about available ADR schemes. Consumer information and education campaigns are one possible approach. National authorities should be involved indirectly in consumer education, namely by providing support (in particular: co-financing) for consumer information and education campaigns carried out by non-governmental consumer organisations. Hopefully, the new European regulatory framework initiated by the two new EU proposals will encourage the creation of a special ADR body for consumer 
Alternative Dispute Resolution for Consumer Cases:

Are Divergences an Obstacle to Effective Access to Justice?

disputes, which will ensure a higher level of consumer protection, raising of consumers' confidence and empowerment.

\section{Conclusion}

Divergences in (C)ADR schemes and also through compensatory collective redress are shown as an obstacle to consumers' effective access to justice. Significant barriers for development of common ADR scheme are shown in different legal culture and history (Anglo-Saxon/Continental), transformation of social state (GDP, investments), social mentality of citizen in the state (Is it safer to go to court? More knowable legal requirements - judicial review?) and others. Slovenian and Croatian examples confirm that a decisive EU action in this field is needed to resolve diversity and uneven geographical and sectorial availability of ADR schemes for consumer disputes. If the development of CADR schemes is left to Member States, the quality of the schemes will be poor in some sectors of the retail market. Good practices of some Member States (Netherlands, United Kingdom, Belgium and other) show how to establish effective out-of-court ADR proceedings, in particular by the use of integrated "quality management systems". In measuring efficiency of the ADR schemes, it is not sufficient to compare quantitative data on cases of ADR entities. The Quality Management System should put focus on the empowerment of all involved parties, and to appropriate behavior and communication between the parties in dispute (C2C, C2B and B2B). The integrated and comprehensive approach of quality management evaluation should also include further analysis of violations and study of perceptions of the involved parties. Consumer confidence and satisfaction should be the key elements of consensual dispute settlement in consumer cases, for the sake of development of a strong, growing and fair market that can particularly help in the times of crisis.

EUs priority has to be the creation of one coherent ADR model for consumers, which should be introduced in all Member States despite divergences in legal systems. Member States should then focus on the question, if the creation of these mechanisms should be funded or not funded by the government or companies through associations or industry. In some countries, consumers pay a small fee for the use of the ADR schemes, e.g. in Germany consumers are charged with a fee up to 25 EUR, while in Slovenia and Croatia in public entities consumers are free of charge and in private entities consumers pay from 25 EUR upwards. Different authors are convinced that a small fee in EU could be even a barrier, because parties may get the impression that the decision-making within ADR bodies may therefore not be fairly and objectively.

Member States will also have to carefully consider the potential of all advantages associated with binding or non-binding legal nature of final decision, which is the main topic of ADR entities to provide adequate legal security as "rule of decision", especially in administrative proceedings. After Henry \& 
Perritt (1987, p. 865) the negotiating rulemaking is the perfect alternative in administrative proceeding, because it resolves "interest disputes" and is similar to legislative process - regulatory negotiation, which refers to decision-making by administrative agencies.

Consumer ADR can be harmonic and proportionate movement for access to justice and also an "added value" as Caponi $(2012$, p. 4) has proposed:

"... mediation should not be a remedy for the inefficiencies of the public civil justice system, but rather should present an "added value" to courts that work effectively and efficiently. For this reason the promotion of mediation should always be accompanied by efforts to improve the efficiency of the civil justice system and not by attempting to limit access to the courts. This point of view implies an identification of the kinds of disputes that would be "better" resolved through informal methods than through legal actions before the courts."

The creation of environment where consumers through education, information and awareness know how to navigate in the Single Market is the benefit and "added value" in the whole ADR process. The real European challenge of effective access to justice is not just its justification but its practice. The heart of real effective access to justice is changing the traditional court practice to the dispute resolution innovation with empowerment requirements. After Mcfarlane (2012, p. 939) the essence of effective dispute resolution innovation 'deserves our full intellectual and affective energy if it is to be a "real" experiment in something new... Sometimes the energy we put into developing new rules seems to be a substitute for the energy needed for trying something new. To be effective innovators, we need to limit our preoccupation with rule-based change and explore other ways to support and build culture change. When we experiment with new processes, we should resist easy orthodoxies and stay open to the possibility of failure.'

Urša Jeretina, B.Sc. holds a University degree in Criminal Justice and Security from the University of Maribor and is about to obtain her Masters of Public Administration Science degree from the University of Administration Ljubljana. She has participated in various projects especially in the field of administrative procedural law and attended in various professional workshops at the University of Ljubljana. She became a mediator within the Rakmo Institute (basic training) and CMA (basic and advanced training). At the Faculty of Law in Zagreb she also finished Erasmus training practice at Croatian Mediation Association CMA. 
Prof. Alan Uzelac, Dr. Sc. is Professor of Civil Procedural Law at the Zagreb University, Faculty of Law, where he teaches Civil Procedure, Arbitration, ADR, Organization of Judiciary, and Protection of Human Rights in Europe. He holds degrees in law and social sciences from Zagreb University. He has been visiting researcher and scholar at a number of universities. As an active member of the International Association of Procedural Law and the German Association for International Procedural Law, he serves on the chief advisory bodies of both organizations (Council, Rat). He was involved in various activities of the European Commission for the Efficiency of Justice (CEPEJ) of the Council of Europe, where he held different functions. Since mid-90s, he was engaged as national delegate of Croatia in the work of UNCITRAL Working Group for Arbitration and Conciliation where he participated in drafting of the several international instruments in the field of alternative dispute resolution. Throughout his career, he was often engaged as expert in various legislative projects. As an international expert he worked in the region and Europe, assisting legal reforms and legal collaboration in Serbia, Bosnia and Herzegovina, Montenegro, Russia and Kosovo. Currently, he is also member of the highest body for judicial appointments and discipline, the State Judicial Council. 


\section{References}

Caponi, R. (2012). Collective Redress in Europe: Current Developments of "class action" suits in Italy. University of Florence.

Davies, J. (2012). How well placed is the optimism surrounding the new ADR/ ODR proposals? Journal of European Consumer and Market Law, 2, 63-64.

Directorate General for Health and Consumers - EC (DG SANCO) (2009). Study on the use of Alternative Dispute Resolution in the European Union. Final report. Civic Consulting of the Consumer Policy Evaluation Consortium.

Directorate General for Health and Consumers - EC (DG SANCO) (2011). Consultation paper: On the use of Alternative Dispute Resolution as a means to resolve disputes related to commercial transactions and practices in the European Union.

Directorate General for Health and Consumers - EC (DG SANCO) (2014). Management plan.

European Commission (2010). Towards Single Market Act I, for a highly competitive social market economy. Communication from the Commission to the European Parliament, the Council, the European Economic and Social Committee and the Committee of the Regions. Brussels: COM (2010) 608 final.

European Commission (2010a). Europe 2020, a strategy for smart, sustainable and inclusive growth. Communication from the Commission Brussels: COM (2010) 2020 final.

European Commission (2011). Alternative dispute resolution for consumer disputes in the Single Market. Communication from the commission to the European Parliament, the Council and the European Economic and Social Committee. Brussels: COM (791 final).

European Commission (2011a). Regulation of the European Parliament and of the Council on a consumer programme 2014-2020. Brussels: COM (707 final), 0340 (COD).

European Commission (2011b). Proposal for a Directive of the European Parliament and of the Council on Alternative Dispute Resolution for consumer disputes (Directive on consumer ADR). Commission staff working paper, Brussels: 1409 final (SEC).

European Commission (2012). Alternative Dispute Resolution and Online Dispute Resolution for EU consumers: Questions and Answers.

European Commission (2012a). Single Market Act II, Together for new growth. Communication from the commission to the European Parliament, the Council, the European Economic and Social Committee and the Committee of the Regions. Brussels: COM (2012) 573 final.

European Commission (2012b). Consumer redress. For all examined countries.

European Commission (2013). Towards a European Horizontal Framework for Collective Redress. Communication from the Commission to the European Parliament, the Council, the European Economic and Social Committee and the Committee of the Regions. COM(401 final).

European Commission (2013a). Regulation (EU) No 524/2013 of the European Parliament and of the Council of 21 May 2013 on Online Dispute Resolution for consumer disputes and amending Regulation (EC) No 2006/2004 and Directive 2009/22/EC (Regulation on consumer ODR). 
European Commission (2013b). Directive No 2013/11/EU of the European Parliament and of the Council of 21 May 2013 on Alternative Dispute Resolution for consumer disputes and amending Regulation (EC) No 2006/2004 and Directive 2009/22/EC (Directive on consumer ADR).

Galič, A. (2012). Zunajsodno reševanje potrošniških sporov v Sloveniji - med pomanjkljivim, sistemsko zgrešenim in protiustavnim. Pravna praksa, 31/32, 6-8.

Goes, P. (2014). Legal Framework relating to Alternative Dispute Resolution in Belgium Public Law. International review for Public Administration, XII (2-3), 9-31.

Henry, H. and Perritt, Jr. (1987). Administrative Alternative Dispute Resolution: The Development of Negotiated Rulemaking and Other Processes. Pepperdine Law Review, 14 (4), 864-928.

Hodges, C. (2012). Current discussions on consumer redress: collective redress and ADR. Annual Conference on European Consumer Law organized by ERA Forum 13,11-33.

Hodges, C., Benöhr, I., \& Creutzfeldt-Banda, N. (2012). A model for a national consumer ADR architecture. Adopted from Consumer ADR in Europe. Centre for socio-legal studies: University of Oxford.

Hodges, C., Benöhr, I., \& Creutzfeldt-Banda, N. (2012a). Essential requirements and key performance indicators. Adopted from Consumer ADR in Europe. Centre for socio-legal studies: University of Oxford.

Hodges, C., Benöhr, I., \& Creutzfeldt-Banda, N. (2012b). Consumer-to-Business ADR Structures: Harnessing the Power of CADR for Dispute Resolution and Regulating Market Behavior. European Civil Justice Systems, The Foundation for Law, Justice and Society in collaboration with the Centre for Socio-Legal Studies, University of Oxford.

Hodges, C., Benöhr, I., \& Creutzfeldt-Banda, N. (2012c). Data on the costs of Consumer ADR schemes. Center for Socio-Legal studies: University of Oxford.

Hodges, C., Benöhr, I., \& Creutzfeldt-Banda, N. (2012d). Consumer ADR in Europe. Oxford, Portland, Oregon. United Kingdom: Hart Publishing.

Hodges, C. \& Money-Kyrle, R. (2012). Safeguards in Collective Actions. European Civil Justice Systems, the Foundation for Law, Justice and Society in collaboration with The Centre for Socio-Legal Studies: University of Oxford.

Juškys, A., Ulbaitè, N. (2012). Alternative dispute resolution for consumer disputes in the European Union: current issues and future opportunities. Issues of business and law, 4, 25-34.

Lindell, B. (2012). Alternative Dispute Resolution and the Administration of Justice - Basic Principles. Scandinavian Studies (1999-2012), 312-344.

Macfarlane, J. (2012). ADR and the Courts: Renewing our Commitment to Innovation. Marquette Law Review, 95 (3), 927-940.

The Commercial Court of Croatia (2013). Annual Report of the Commercial Court in period 2010-2013. Zagreb.

The Gallup Organization (2011). Flash Eurobarometer 299, Consumer attitudes towards cross-border sales and consumer protection. The survey requested by EUROSTAT and DG-SANCO and coordinated by the Directorate-General for Communication.

The High Commercial Court of Croatia (2013). Annual Report of the High Commercial Court in period 2010-2013. Zagreb. 
Urša Jeretina, Alan Uzelac

The High Commercial Court of Croatia (2013). Annual Reports for court-annexed mediation of the High Commercial Court in period 2010-2013. Zagreb.

The Supreme Court of Slovenia (2013). Annual Reports for court-annexed mediation of the District and County Court in period 2009-2013. Ljubljana.

The Supreme Court of Slovenia (2013). Annual Reports of the Supreme Court in the period 2010-2013. Ljubljana.

TNS Opinion \& Social (2011). Special Euro barometer 342, Consumer Empowerment. The survey requested by EUROSTAT and DG-SANCO and coordinated by the Directorate-General for Communication.

Uzelac, A., Aras, S., Maršić, M., Mitrović, M., Kauzlarić, Ž., \& Stojčević, P. (2010). Aktualni trendovi mirnog rješavanja sporova u Hrvatskoj: dosezi i ograničenja. Zbornik Pravnog fakulteta u Zagrebu, 60 (3), 1265-1308.

Zabel, B. (1999). Tržno pravo. Ljubljana: Gospodarski vestnik. 
POVZETEK

1.01 Izvirni znanstveni članek

\title{
Alternativno reševanje potrošniških sporov: Ali so razlike zapreka za učinkovit dostop do pravnega varstva?
}

\begin{abstract}
Ključne besede: alternativno reševanje potrošniških sporov (ARPS), varstvo potrošnikov, sheme ARS, kolektivne odškodnine, poenotenje in harmonizacija prava EU, sheme ARPS v Sloveniji in na Hrvaškem
\end{abstract}

Potrošnja je del našega vsakdana, zato je učinkovito varstvo pravic potrošnikov tudi eden od ključnih elementov za delovanje notranjega trga Evropske unije (EU). Delovanje enotnega notranjega trga je koristno za potrošnike in podjetja, saj podpira ustvarjanje delovnih mest, spodbujanje rasti in konkurenčnosti ter inovacije. A kljub temu bi lahko EU omogočila večjo enotnost v ključnih sektorjih potrošnje, ki so razdrobljeni ali očitno pomanjkljivo konkurenčni. Potrošnik pri uveljavljanju pravnega varstva ostaja še zmeraj šibkejša stranka v postopku spora. Tradicionalni sodni postopki niso vedno praktičen in stroškovno primeren način reševanja potrošniških sporov, saj je za potrošnika ekonomska škoda skupaj sodnimi stroški postopka nesorazmerna, še posebej v sporih majhne vrednosti (10-20 EUR). Izgube evropskih potrošnikov zaradi težav s kupljenim blagom ali storitvami so ocenjene na 0,3\% evropskega BDP.

Nekateri avtorji menijo, da so postopki alternativnega reševanje sporov (ARS) učinkovito, hitro in poceni orodje za reševanje sporov med potrošniki in podjetji. Alternativno reševanje potrošniških sporov (ARPS) je lahko koristen instrument, ki pomaga potrošnikom do zavedanja svojih pravic do pravnega varstva. $V$ teoriji so postopki ARPS predstavljeni kot prilagodljiv in hitrejši način uveljavljanja pravic potrošnikov, ki zagotavlja dragocene informacije o potrebah strank v postopku spora, hkrati pa ohrani zaupnost, enakopraven položaj strank v postopku spora ter povečuje zadovoljstvo potrošnikov. Kljub dobrim ocenam v teoriji ta institut v praksi še ni povsem zaživel. Ocenjuje se, da na obeh straneh, pri podjetjih in pri potrošnikih, ni ustrezne ozaveščenosti o obstoju shem ARS in njihovih koristi. V tem članku smo analizirali koncept ARPS skozi kompenzacijske kolektivne odškodnine ter obravnavali ali trenutne pravne pobude EU prispevajo tudi k povečanju zaupanja potrošnikov v notranji trg držav članic EU. Posebna pozornost je namenjena različnim oviram za razvoj shem ARS, ki se kažejo ne samo v različnosti shem ARS, temveč tudi v metodah ocenjevanja in merjenja učinkovitosti uporabe ARPS. Evropska Direktiva o ARPS in Uredba o spletnem reševanju sporov (SRS) sicer kažeta na začetno nastavitev prilagodljivih pravil, ki bi zagotavljali kakovost reševanja sporov med subjekti v EU. Vendar pa so tovrstne pobude EU doslej 
Urša Jeretina, Alan Uzelac

pustile veliko odprtih vprašanj glede nadzora in financiranja shem ARPS ter potreb zgolj v zvezi z notranjim usklajevanjem praks ARPS v državah članicah EU. Primeri precejšnjih razlik predvsem na področjih energije in telekomunikacij se kažejo v postopkih ARPS sosednjih držav Zahodnega Balkana, kot sta Slovenija in Hrvaška. 